\title{
Firms in International Trade
}

\section{Federico J. Díez, Jesse Mora, and Alan C. Spearot}

\begin{abstract}
Firms play a critical role in the global economy. In this paper, we survey the behavior of firms in the international economy, both in theory and in the data. We first summarize the key empirical facts that motivate the study of firms in trade. Then, we detail recent theoretical developments on the micro-foundations of firm behavior in an international context, focusing on how firms select into exporting, and how firms respond to international shocks. Finally, we turn to a "real world," empirically focused view of exporting, beginning with the growth dynamics of firms expanding to global markets, and then addressing the critical financing decisions firms make when engaging in international commerce. We conclude with directions for future research.
\end{abstract}

\section{JEL Classifications: F10, F12, F14}

Keywords: firm heterogeneity, international trade, exporters

Federico Díez is an economist in the Research Department of the Federal Reserve Bank of Boston. Jesse Mora is an assistant professor in the economics department at Occidental College. Alan C. Spearot is an associate professor in the economics department at the University of California, Santa Cruz. Their email addresses are federico.diez@bos.frb.org, jmora@oxy.edu, and aspearot@ucsc.edu, respectively.

The view expressed herein are those of the authors and do not indicate concurrence by other members of the research staff or principals of the Board of Governors, the Federal Reserve Bank of Boston, or the Federal Reserve System..

This paper, which may be revised, is available on the web site of the Federal Reserve Bank of Boston at http://www.bostonfed.org/economic/wp/index.htm.

This version: December 2016 


\section{Introduction}

The last 20 years have witnessed a substantial expansion in research studying firms in the global economy. This literature on "firms in trade" studies how firms, in particular the most productive and typically very large firms, self-select into exporting and shape the landscape of international trade and investment. These large firms in international trade are responsible for decisions that create linkages between major sectors of the world economy and affect the lives of billions of workers worldwide.

One needs to look no further than some of the most well-known businesses to understand the importance of firms in shaping world trade flows. For example, Boeing, the largest exporter in the United States, exported $\$ 29$ billion in 2009, or approximately 1.8 percent of total exports from the United States. ${ }^{1}$ This number is more impressive when we consider that there are approximately 300,000 exporters in the United States (U.S. Census 2013). Another firm, Fontera-a large dairy producer and New Zealand's largest company-is responsible for 20 percent of New Zealand merchandise exports. ${ }^{2}$ There are many more such examples. In fact, Bernard et al. (2007) document that while exporting firms in the United States are a minority of manufacturing firms, not all exporters are the same and a very small share of exporting firms (11 percent) account for a very large share of exporting revenues (92 percent).

Clearly, firms play an important role in exports from the United States and other developed economies in a wide range of industries. And, as we discuss below, these anecdotes are just the tip of the iceberg in how firms, in particular large firms, have a profound effect on the international economy. The decisions of the modern exporter are complex and have far-reaching implications for the firm's financial well-being, the workers who are employed by the firm, and the consumers who enjoy its products.

\footnotetext{
${ }^{1} \mathrm{http}: / /$ www.slate.com/articles/business/exports/2010/11/the_boeing_co.html

${ }^{2}$ http://www.nzdairycareers.co.nz/?page=Dairy_Industry\&subpage=Dairy_Facts
} 
Perhaps surprisingly, in spite of these anecdotes, the focus on firms is a relatively new development. The classic literature on trade focused mainly on primitives over country and industry characteristics to predict the pattern and implications of trade. In its most basic and general form, the classic trade model predicts that countries tend to export goods in which they have a comparative advantage, which, through the lens of most models, corresponds to products with a low within-country autarky price when compared with the within-country autarky price of other countries. These price differentials, in autarky, can be driven by factor endowments, technology differences, or a combination of the two. That is, a relatively low autarky price is observed in products with higher productivity, and in goods that make intensive use of a relatively abundant factor of production.

Even before the focus on the role of firms, testing the classic trade modelsperhaps to support policy evaluation-was of first-order importance. Indeed, before the firms-in-trade revolution, many rounds of the World Trade Organization (WTO) occurred, and other agreements were signed that were specific to certain industries (for example, the U.S.-Canada Automotive Pact). Unfortunately, testing the classic trade models has proven challenging. General statements of comparative advantage exist (Deardorff 1984), although since the counterfactual of autarky is a rare, if not a non-existent, occurrence, the model is virtually impossible to test. ${ }^{3}$ Further, when focusing on endowment differences, one rarely observes a precise accounting for the composition of trade that is related to factors of production, especially across many countries. Thus, starting with Leontief (1953) and Vanek (1968), researchers have adopted assumptions on technology to link the classic, endowment-based results to the imputed "factor content of trade" (for example, the automobile industry tends to export $\mathrm{X}$ amount of domestic capital per vehicle). This literature

\footnotetext{
${ }^{3}$ One exception exists to this data issue, which is Bernhofen and Brown (2004). Here, the authors use refined historical data from $19^{\text {th }}$ century Japan, when autarky was observed, to test the general theory of comparative advantage. They find robust support for the theory, where upon opening to trade, Japan exported goods for which the autarky price was relatively low.
} 
has provided a long list of competing papers, providing mixed support for the endowment-based models. ${ }^{4}$

Beyond the empirical challenges, it also became clear that the classic literature on trade was missing the mark in a more important area-the model itself. To see why, consider a well-known company such as General Motors (GM), which, during the 1950s and 1960s, had an approximately 50 percent share of the domestic market. Yet, the classic trade models assumed that firms were small price takers, exercising no strategy over what to produce, where to produce, or how to produce. This is particularly important when considering the international dimension of these models. In the classic models, every firm used the same technology, never bought imported inputs, and made simple production decisions based on domestic factor prices and the homogenous domestic price. Further, companies like GM often produced many product varieties, and these varieties were traded between countries, usually in both directions, in stark contrast with the classical prediction that countries export a homogeneous product in one industry and import in another. Simply put, the models did not match reality, and theory needed to catch up to provide a realistic and quantifiable theory to evaluate the costs and benefits of trade.

In this paper, we survey the progression of firms in the trade literature, from the groundbreaking work of Paul Krugman $(1979,1980)$, which changed the way we model international trade, to the most recent theoretical and empirical research, which evaluates how firms evolve in the global economy and how firms finance their export operations. We begin in section one with some basic facts about firms in trade that have guided the literature and stand in contrast with the classic, aggregate treatment of world trade. In the second section, we outline the canonical frameworks for modeling the exporting decisions of heterogeneous firms and focus on how trade costs and trade policy affect these decisions. In the third section, we take an empirical view of how exporting evolves over time and of how this may

\footnotetext{
${ }^{4}$ Earlier tests of the Heckscher-Ohlin theorems include Leontief (1953), Leamer (1980), Trefler (1993, 1995), Davis and Weinstein (2001). Very recent work in Morrow and Trefler (2016) provides the most rigorous support of the $\mathrm{HO}$ results to date.
} 
influence future firm performance. In the fourth section, we focus on how firms finance their exporting operations and how credit constraints can alter the pattern of trade. Finally, in the last section, we conclude with ideas for future directions in the literature.

1 Empirics of Firms in Trade

As mentioned in the introduction, one of the main issues with the classical trade model is its inability to explain the presence and impact of firms in the global economy. With the increased availability of firm-level data in the 1990s, it became clear that the problem was not only the model's inability to explain the behavior of a few firms, but also its inability to explain systematic trade patterns across many countries and industries. In this section, we focus on the following four stylized facts that are difficult to reconcile with the standard trade model and that have formed the basis for the firms-in-trade revolution: (1) few firms export, even in a country's "exporting" sectors; (2) exporting firms are different from non-exporting firms in all

sectors; (3) a few, very-successful exporting firms account for most exports; and (4) exporting firms start small and most fail, but those that survive tend to expand. In subsequent sections, we outline the leading framework developed to understand these empirical findings and detail how this framework allows international trade economists to answer new, policy-relevant, questions.

\subsection{Few Firms Export}

Most classic theories of trade, as well as the most basic version of Krugman's pioneering work on firms in trade, assume that all firms have the same likelihood of exporting. However, this is in stark contrast with data for the United States and other countries. Simply put, very few firms export, even in export-oriented industries.

To begin, consider first the highly influential work of Bernard et al. (2007), which outlines many stylized facts for U.S. exporters and importers. In contrast with 
the predictions of the classic models, the authors find that only 18 percent of U.S. firms export and those firms that do, export only 14 percent of their total shipments, on average. Even within the largest U.S. manufacturing sectors-fabricated metal products, printing and related support, and food manufacturing-only 14 percent, 5 percent, and 12 percent, respectively, of firms in those sectors export. These few exporters also tend to export a small share of their total shipments; 12 percent, 14 percent, and 15 percent, respectively.

Table 1.1: Exporting by Industry in Colombia

\begin{tabular}{lccc} 
Industry & $\begin{array}{c}\text { Percent } \\
\text { of Firms }\end{array}$ & $\begin{array}{c}\text { Percent of } \\
\text { Exporters }\end{array}$ & $\begin{array}{c}\text { Mean Ratio of } \\
\text { Exports to Total } \\
\text { Revenue }\end{array}$ \\
\hline Food Manufacturing & 16.9 & 23.6 & 27.8 \\
Beverages & 2.1 & 20.0 & 20.9 \\
Tabaco Products & 0.1 & 91.2 & 16.0 \\
Textiles & 4.4 & 52.5 & 16.9 \\
Apparel & 10.2 & 58.7 & 30.7 \\
Leather Products (Excluding Footwear) & 1.5 & 77.9 & 44.7 \\
Footwear and Related Products & 1.8 & 55.4 & 18.6 \\
Wood Products Manufacturing & 1.6 & 32.9 & 26.7 \\
Paper, Cardboard And Derivatives & 2.2 & 60.4 & 22.6 \\
Printing and Related Support & 7.9 & 46.2 & 18.9 \\
Chemical Manufacturing & 12.3 & 56.3 & 17.8 \\
Rubber Products & 1.3 & 59.4 & 20.4 \\
Plastic Products & 8.5 & 54.6 & 14.8 \\
Glass And Glass Products & 0.7 & 73.9 & 30.0 \\
Nonmetallic Mineral Products & 2.9 & 40.1 & 27.2 \\
Cement and Other Products & 1.7 & 26.1 & 18.9 \\
Primary Metal Manufacturing & 2.2 & 49.9 & 31.8 \\
Fabricated Metal Manufacturing & 8.3 & 51.4 & 20.3 \\
Automotive Vehicles and Parts & 3.8 & 64.4 & 21.3 \\
Other Transportation Vehicles and Parts & 0.6 & 49.9 & 24.7 \\
Other Manufacturing Industries & 9.0 & 50.1 & 20.8 \\
\hline
\end{tabular}

Note: Authors' calculations based on data from Colombia's customs (DIAN) and supervising (SIREM) agencies from 1995 to 2011. Column 2 is the average percentage of manufacturing firms in the given industry; Column 3 is the average percentage of firms within the given industry that export; and Column 4 is the average ratio of exports to total shipments within a given industry, for firms that export.

While these results could be explained by the fact that the United States has a large domestic market, it is also the case that exporting is not ubiquitous for firms in 
other, smaller and developing markets. Indeed, using data from Colombia to corroborate the findings in Bernard et al. (2007), we find a similar pattern in Table 1.1 , where exporting tends to be a small share of total sales (22 percent on average). In Colombia's largest manufacturing industries-food manufacturing, apparel, and chemical manufacturing-23.6 percent, 58.7 percent, and 56.3 percent of firms in each of those sectors export, respectively. Further, for these same industries, the mean ratio of exports to total revenue for exporting firms is 27.8 percent, 30.7 percent, and 17.8 percent, respectively. ${ }^{5}$ Clearly, many firms in Colombia do not export, even in the largest sectors, and those that do, tend to earn most of their revenues from the domestic market.

\subsection{Exporters Are Different from Non-Exporters}

While our first stylized fact makes it clear that few firms export, it is not clear why this is so. Indeed, it may be that firms are simply reaching different consumers, some of whom happen to be abroad, and that there are no fundamental differences between exporters and non-exporters. Alternatively, it could be the case that exporters are just different from non-exporters in other characteristics, and that these characteristics induce selection into exporting. The data clearly support the latter hypothesis, whereby exporters are fundamentally different from nonexporters, even in exporting sectors. It is this self-selection that forms the basis for most of the theoretical work that we outline in the sections that follow.

Again drawing on the work of Bernard et al. (2007), U.S. firms display numerous export "premia": exporters have higher employment, shipments, valueadded per worker, productivity, wages, capital per worker, and skill per worker. Casas, Díez, and González (2016) find a similar exporter premium for Colombian

\footnotetext{
${ }^{5}$ Unlike the data used in Bernard et al. (2007), our data are available only for the largest producers, and the findings here exclude the firms that are less likely to participate in the export market. We expect that these numbers are overstated and will decrease when smaller manufacturing firms are included. For further evidence, using a larger (but older) data sample of Colombian firms, Brooks (2006) finds that only 10-20 percent of Colombian manufacturing firms exported in the 1980s and that the average export share was around 20 percent.
} 
firms, which we have replicated in Table 1.2. For example, they find that exporters have higher wages, value-added per worker, income per worker, capital per worker, productivity, and investment per worker. ${ }^{6}$ The key finding in these and other studies is that firm productivity is correlated with exporting; that is, in all sectors, the most-productive firms are more likely to export. ${ }^{7}$

Table 1.2: Differences between Exporting and Non-Exporting Firms Wage Value- Income Capital Investment Productivity Added

\begin{tabular}{lcccccc}
\hline Exporter & 0.299 & 0.408 & 0.350 & 0.347 & 0.446 & 0.223 \\
Premia & $(0.0156)$ & $(0.0218)$ & $(0.0239)$ & $(0.0324)$ & $(0.0346)$ & $(0.0250)$ \\
Obs. & 25,979 & 26,042 & 26,130 & 26,130 & 25,091 & 26,130 \\
\hline
\end{tabular}

Notes: Standard errors (in parentheses) clustered by firm; all estimates have statistical significance at the 1 percent level. Productivity is calculated using the method found in Gandhi, Navarro, and Rivers (2016) and for the other estimates the dependent variables are measured in billions of Colombian pesos of 2005 per worker. All specifications include controls of year and sector. Table taken from Casas, Díez, and González (2016).

\subsection{Exporting Is Very Concentrated}

While the data show that exporting firms are different from non-exporting firms, the data also show that there is heterogeneity even within exporting firms. Surprisingly, data showing how rare it is for firms to export may actually overstate how much exporting actually takes place. For example, again drawing on Bernard et al. (2007), exporters that sell only one product to one export market represent 40 percent of exporting firms in the United States, but only 0.2 percent of the export value. In contrast, firms exporting five or more products to five or more countries

\footnotetext{
${ }^{6}$ For other studies identifying differences between non-exporters and exporters, and even differences within exporting firms, see Eaton, Kortum, and Kramarz (2011), Mayer, and Ottaviano (2008), Casas, Díez, and González (2015), and Clerides, Lach, and Tybout (1998).

${ }^{7}$ While most papers, using various measurements of firm productivity, find evidence that only the mostproductive firms export, the most common measurement of productivity, TFP, is calculated by estimating the production function. Gandhi, Navarro, and Rivers (2016) argue that estimating the production function suffers from bias and find that correcting for the bias, in the case of Colombia and Chile, results in smaller productivity differences in most cases and no differences in others.
} 
account for 13.7 percent of all exporting firms and 92.9 percent of export value. ${ }^{8} \mathrm{~A}$ similar pattern appears in data from Colombia. As shown in Table 1.3, the share of single-product, single-destination exporters in Colombia is 16 percent, but these firms account for only 0.3 percent of the export value. On the other hand, the share of firms exporting more than 10 products to more than 10 countries is 11.5 percent of firms, but these firms account for almost 60 percent of the export value. Clearly, exporting is concentrated and dominated by a few, very-successful firms that export many products to many destinations, and models of firms in trade must consider both selection into different destinations as well as an expanded product set.

\footnotetext{
${ }^{8}$ Another way to analyze the importance of large firms is to focus only on the top exporters (disregarding the number of destinations or products). For example, Freund and Pierola (2016) focus on the top five exporters in 40 developing countries, and find that these "superstars" on average account for one third of export value and over half of export growth over a five-year period.
} 
Table 1.3: Multiproduct/Country Firms

(a) The share of firms

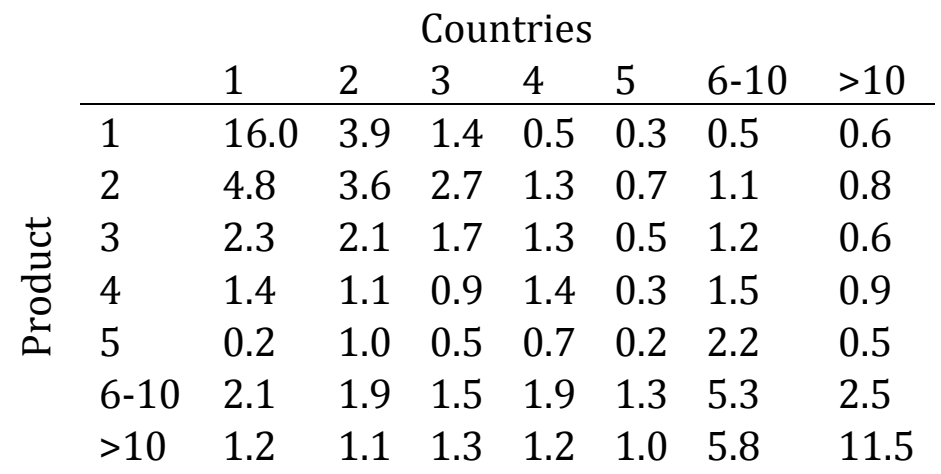

(b) The share of export value

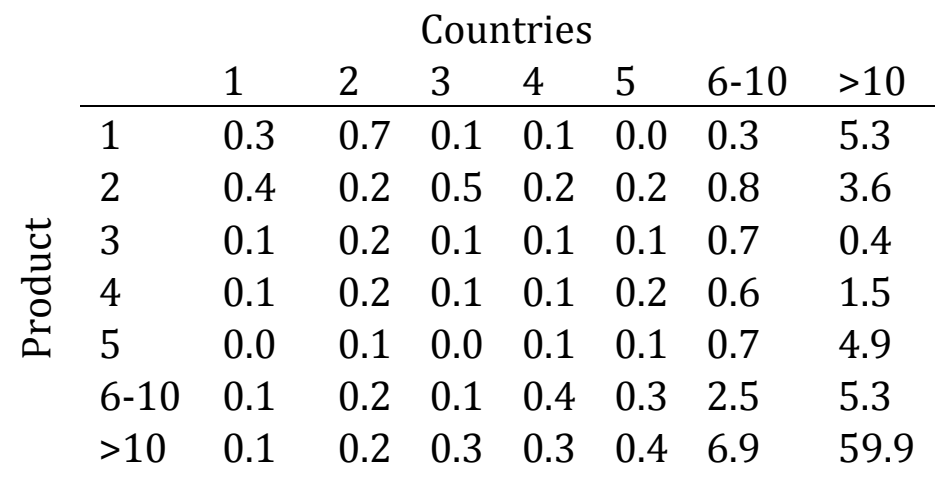

Note: Calculations based on data from SIREM and DIAN/DANE for 2013. Table taken from Casas, Díez, and González (2016).

\subsection{Exporting Firms Start Small and Most Fail, but Those That Survive Expand}

The final stylized facts we discuss are the survival rate of exporters and the growth of those that do survive. Given the long-run nature of the classic literature, dynamics were rarely considered (along with the firms themselves). However, in many countries, new firms attempt to export and others exit in every year. In Table 1.4 we summarize these statistics for Colombia, where 34 percent of exporters in 2000 were entrants (new exporters), 23 percent were continuing exporters (firms that continuously exported between 1994 and 2000), and 43 percent were experienced exporters (firms that exported in some but not all years between 1994 and 2000). These statistics, however, understate the importance of continuing exporters, which accounted for 70.5 percent of the export share in 2000. Further, continuing 
exporters export an average of 5.6 million USD per firm (compared with 1.2 million per firm for experienced exporters and 0.1 million per firm for entrants).

Table 1.4: Exports by Firm Type

\begin{tabular}{lccccc} 
Firm Type & $\begin{array}{c}\text { Number } \\
\text { of Firms }\end{array}$ & $\begin{array}{c}\text { Share of } \\
\text { Firms } \\
(\%)\end{array}$ & $\begin{array}{c}\text { Exports } \\
\text { (mn, USD) }\end{array}$ & $\begin{array}{c}\text { Share of } \\
\text { Exports } \\
(\%)\end{array}$ & $\begin{array}{c}\text { Exports } \\
\text { per Firms } \\
\text { (mn, USD) }\end{array}$ \\
\hline Continuing Exporters & 1,630 & 23.2 & 9,098 & 70.5 & 5.6 \\
Experienced Exporters & 3,016 & 43.0 & 3,622 & 28.1 & 1.2 \\
Entrants & 2,372 & 33.8 & 179 & 1.4 & 0.1 \\
\hline
\end{tabular}

Note: Continuing Exporters are firms that exported every year from 1994 to 2000; Experienced Exporters are firms that exported both in 2000 and in one, but not every, year before 2000; and Entrants are firms that exported in 2000 for the first time.

While the importance of continuing exporters is clear, new exporters are important in other dimensions. Although entrants tend to start small, and most will not export beyond one year, those firms that do succeed tend to grow and become important contributors to export growth. As shown in Table 1.5, exports per firm increase for all firm types, but exports per firm increase at a faster rate for entrants. Indeed, after five years, exports per firm for entrants increase by a factor of 22 (compared with a doubling for continuous exporters and tripling for experienced exporters), and after 10 years they increase by a factor of 51 (compared with four for continuing exporters and seven for experienced exporters). Additionally, after a few years of exporting, the hazard rate (the share of firms that exit the export market at time $t$, conditional on having survived the previous year) is almost the same for all firm types. The key difference is the hazard rate in 2001, which is 60 percent for entrants (their initial year). In contrast, the hazard rate is 7.4 percent for continuing exporters and 27.1 percent for experienced exporters. Clearly, new exporters have a high likelihood of failure, but, conditional on success, they grow quickly and their international operations stabilize in line with experienced and continuing exporters. 
Table 1.5: Export Dynamics by Firm Type

\begin{tabular}{llcccc} 
& \multicolumn{1}{c}{ Firm Type } & 2000 & 2001 & 2005 & 2010 \\
\hline Exports & Continuing Exporters & 5.6 & 5.3 & 9.7 & 21.5 \\
per Firm & Experienced Exporters & 1.2 & 1.5 & 3.8 & 8.0 \\
(mn, USD) & Entrants & 0.1 & 0.5 & 1.7 & 3.9 \\
\hline \multirow{3}{*}{ Hazard Rate } & Continuing Exporters & - & 7.4 & 3.9 & 4.6 \\
& Experienced Exporters & - & 27.1 & 14.6 & 8.1 \\
& Entrants & - & 59.2 & 17.1 & 5.4 \\
\hline
\end{tabular}

Note: Continuing Exporters are firms that exported every year from 1994 to 2000; Experienced Exporters are firms that exported both in 2000 and in one, but not every, year before 2000; and Entrants are firms that exported in 2000 for the first time. Hazard rate is the failure rate for exporters (the percentage of firms that exit the export market) at time $t$, conditional on having survived at $t-1$.

New exporters may start small and may not seem important, but they grow quickly if they survive and, in aggregate, are the key to future export growth. Indeed, Eaton et al. (2007) find, for example, that new exporting firms will account for almost half of total export growth within a decade. Overall, the dynamics discussed here have spurred a new literature trying to explain why first-time exporters start small, why so many firms stop exporting given the high sunk costs to export, why conditional on export survival firms tend to expand, and even why export failure may have lasting negative consequences for firms. Understanding these firms and answering the questions posed here are fundamental to understanding export dynamics and export growth.

\subsection{Motivating New Models}

To summarize the key empirical facts from this section, it is clear that there is substantial heterogeneity in international trade that originates at the firm level. Not all firms export, and those that do tend to be more successful than non-exporters. Even within the set of active exporters, there is substantial heterogeneity. The biggest exporters tend to be really big. They account for a massive share of exported value. Further, there is substantial variation in whether exporters succeed. Some fail and exit quickly. Others succeed and expand over time. 
On almost every dimension of international commerce, there is selection at the firm level. Indeed, this selection has led economists to develop trade models with heterogeneous firms to explain this selection, and raise new questions that cannot be explained by classic models. For example, are the export premia the result of exporters "learning from exporting" or is there something about the exporting firms that allows them to become more successful and able to cover the additional costs of exporting? Or can reallocation of resources from non-exporting firms to exporters raise aggregate productivity and thus also add a new channel for gains from trade? We now outline the basic models used to answer these questions.

\section{$2 \quad$ Modeling Firms in Trade}

With some basic stylized facts in hand, we now develop the theory behind the firmsin-trade revolution. For modeling firms in international trade, the first question to consider is whether firms are "big" or "small," which determines precisely whether these firms take into account the effects of their actions on "economic aggregates." Do firms have enough purchasing power to affect the wage? Do firms take into account the direct effect of their output choices on the incentives of other firms (à la Cournot)? Or do firms act small, either taking price as given or only having control over a small "monopoly" market for their own variety?

Despite the analytical complications from doing so, an early literature on firms in trade focused on oligopoly as the main framework for modeling strategic decisions. For example, Brander and Krugman (1983) and Brander and Spencer (1985) each evaluate the effects of trade costs (the former) and subsidies (the latter) on the strategic behavior of firms in an oligopoly framework. Eaton and Grossman (1986) determine the optimal tariff in a conjectural variations model, focusing on the how the nature of competition determines this optimal policy. ${ }^{9}$ While enlightening for policy discussions over tariffs and subsidies, the literature on strategic trade suffers from an analytical complexity that severely limits its ability to

\footnotetext{
${ }^{9}$ Conjectural variations is a modeling strategy where firms assume, or "conjecture," the response of other firms to their own strategic decisions.
} 
appropriately represent firms in international trade. That is, firm-heterogeneity in productivity, one of the hallmarks of recent empirical work in trade, is very difficult to model in an environment with large firms that have market power within and across varieties. ${ }^{10}$ This also makes it difficult to analyze self-selection into exporting by productivity, which is at the center of positive and normative questions at the intersection of trade policy and the theory of the firm.

Recognizing the difficulty with oligopolistic competition, a significant majority of empirically and theoretically focused work on international trade, starting with the seminal work of Krugman $(1979,1980)$, begins with the assumption of monopolistic competition. Monopolistic competition assumes that firms have market power in their own varieties but do not take into account the effects of their decisions on economic aggregates (price index, wage, marginal utility of income, etc.). To study where this takes us (and more importantly, where it does not), we begin our discussion of firms and trade with a simplified version of Krugman (1979, 1980), which, in many ways, has formed the basis of our understanding of firms in the international economy.

\subsection{The Krugman Framework}

The Krugman framework delivers a parsimonious, general equilibrium model in which consumers love variety and firms can exploit economies of scale. It is hard to overstate its simple genius; consequently, the foundations of this model have formed the basis for the vast majority of work on firms in trade since its publication.

The starting point for the Krugman framework is a set of consumers who have preferences over a variety of goods. Specifically, consumers have constant elasticity of substitution (CES) preferences of the following form:

\footnotetext{
${ }^{10}$ Recent research allows for a more general treatment of market power with firm heterogeneity by assuming that the most productive firms enter the market first. See Atkeson and Burstein (2008), Eaton, Kortum, and Sotelo (2015), and Gaubert and Itskhoki (2015).
} 


$$
U=\left(\sum_{j=1}^{N} q_{j}^{\frac{\sigma-1}{\sigma}}\right)^{\frac{\sigma}{\sigma-1}}
$$

Here, there is no outside good, and consumers earn utility only in the differentiated sector, with $\sigma$ representing the elasticity of substitution across $N$ varieties, indexed by $j$. There are $N$ available varieties, with each variety produced by one firm. In the closed-economy model that follows, all varieties must be produced domestically.

Firms in the model are very simple. To enter the market, firms must hire $F$ workers to set up the firm, where these workers undertake upfront costs, such as $\mathrm{R} \& \mathrm{D}$ and marketing. Each worker is paid a wage $w$, and all firms have the same technology. After entering, firms produce varieties using additional labor, with one unit of labor required for each unit of production. When pricing their individual variety, firms take aggregates as given, but behave as monopolists in their own variety. Firms enter until total profits are equal to zero.

In its most basic form, there are three equilibrium conditions in the Krugman framework. The first is pricing. While we generalize the pricing decision by firms rigorously in later sections, for now, we simply assert that given CES preferences and the assumption of monopolistic competition, firms charge a price that is a constant mark-up above marginal cost:

$$
p=\frac{\sigma}{\sigma-1} w
$$

As $\sigma$ rises and varieties become more substitutable, the mark-up above marginal cost falls. Of course, as wages rise, prices do so proportionally. ${ }^{11}$

The second equilibrium condition is free entry; firms enter until total profits equal zero. This condition yields the following "break-even" production level for each firm:

$$
q=(\sigma-1) F
$$

Before introducing the third condition, notice that optimal prices and quantities in the CES Krugman model are the same for all firms. This results from the assumption that all firms have identical technology. Given the statistics on firm-level trade

\footnotetext{
11 This is an artifact of CES preferences, a point we return to later.
} 
presented in section one, this is a key downside of the Krugman framework that will be enhanced in later sections.

Finally, the last condition is labor market clearing. Here, a labor market of size $L$ must support all labor demand by $N$ firms, whether it be fixed upfront labor demand or variable labor requirements for production. By setting demand equal to supply, we have:

$$
N=\frac{L}{\sigma F}
$$

Here, the number of varieties that consumers value due to CES preferences increases in the size of the market. This completes the characterization of the closed economy.

Krugman's model can be extended "internationally" in any number of ways (for example, many countries, asymmetric labor endowments, tariffs), but the easiest way to study the impact of trade on the equilibrium is simply to double $L$. This represents an experiment of one market integrating with another market of equal size. With this experiment, and the three equilibrium conditions above, it is clear that the only change in the equilibrium is the number of varieties available to the consumer in each market. Pricing does not change relative to the wage, since pricing under CES is a constant mark-up over marginal cost. Output per firm does not change because the mark-up does not change with market size and firms enter until zero profits are reached. The number of varieties per country does not change, but since trade is free, the number of varieties available to each consumer has risen by a factor of two. Thus, consumers gain from trade through an expanded variety set.

\subsubsection{Moving Beyond Krugman}

The Krugman model was never meant to precisely match the characteristics of firms in the global economy. Rather, its main objective was to present a model in which economies of scale lead to trade between otherwise-identical countries. Instead of 
trading endowments as embodied in goods, countries are trading varieties of similar products.

It does not take an expert to realize that the Krugman framework-in particular, the version presented above-is missing some other key features of the data that may be important. Again, as in the classic literature, all firms are the same size, operating with the same technology, and presented with the same opportunities to export. In reality, firms typically have different technologies, and those firms with better technology are typically able to export more readily. To this end, a great majority of research studying firms in trade has used the fundamental insight of Krugman within expanded models with heterogeneous technology and other firm attributes. While maintaining the assumption of monopolistic competition, researchers then appeal to probability distributions that define firm attributes to describe the mix of firms and elegantly evaluate how policy and geography affect the mix of firms serving a given market. We now outline a basic framework of firms and trade that summarizes this literature, and the role of trade costs and trade policy in guiding the landscape of international commerce.

\subsection{Exporting and Monopolistic Competition}

In serving an export market, we assume that firms choose quantities to maximize profits. To reach the destination market, firms must first build their product at a cost $c$ per unit, and may pay a host of costs related to trade and trade policy. Specifically, there are four costs of trade that may affect the decision to sell abroad. The first is the melting iceberg trade cost, $\tau>1$, which is precisely the number of units of a good that a firm must produce for one unit to reach the destination market. There are a number of ways to interpret this trade cost. Explicitly, there is a possibility that goods are stolen or damaged en route, and therefore to fill a customer's order there is an expectation that more goods are sent than is required. In reality, many firms do not send extra goods, but instead insure against this probability; hence, $\tau$ may also be interpreted in this way. Another interpretation of the iceberg cost is in the compounded costs of financing that occur over time as a 
good is shipped from one location to the next, or the compounded risk from shipping (Schmidt-Eisenlohr (2013), see section four).

Exporting firms may also be subject to a per-unit or specific cost, $s$. This cost is also related to distance, and can be easily interpreted as the physical cost of moving the good, whether due to weight or weight over a distance. ${ }^{12}$ Further, some trade policy measures are assessed per unit (as opposed to as a percentage of value). In recent work, using Norwegian firm-level data, Irarrazabal, Moxnes, and Opromolla (2015) estimate that specific trade costs are 14 percent of the median price of traded goods.

There are also fixed costs of export, $F_{x}$ which do not depend on output. These costs tend to be interpreted as organizational, logistical, or other administrative costs involved in shipping the good from the plant to the customer in another market. Often, these costs are referred to as "red tape," and many occur at the port of entry. Indeed, in a recent survey by the OECD-WTO (2015), countries were almost twice as likely to report trying to improve general border procedures, and 30 percent more likely to report trying to improve transport infrastructure in an effort to facilitate more trade than they were to reducing explicit policy costs and fees. ${ }^{13}$

A final cost related to international trade is the import tariff, which is typically ad valorem and assessed on the value of the good when it arrives at the destination. To model the tariff, it is usually assumed that if the consumer pays a price $p$, the firm receives a price $p / t$, where $t$ is the tariff factor (one plus the ad valorem tariff). This particular valuation method is called "Cost of Insurance and Freight," or CIF, and it will form the basis of our treatment of trade costs in the model that follows. ${ }^{14}$

\footnotetext{
${ }^{12}$ For example, fuel costs are technically the cost of energy required to move a specific mass over a distance.

${ }^{13}$ See Figure 2.17 in https://www.wto.org/english/res e/booksp e/aid4trade15 e.pdf

${ }^{14}$ An alternate method, "Free On Board" or FOB, is used by a handful of countries, and levies the duty on the value of the good net of the cost of insurance and freight. Johnson (1966) discusses the way in which CIF valuation naturally discriminates against exporters from distant countries compared with FOB valuation.
} 
Having defined the costs of exporting, we now move to defining the objective function of the firm serving a foreign market. Above, we defined products by $j$, and, below, we assume that firms each produce one product. Thus, the profit function of an arbitrary firm $i$ selling to an export market is written as:

$$
\Pi_{i}=\frac{1}{t} p\left(q_{i}\right) q_{i}-\tau c_{i} q_{i}-s q_{i}-F_{x}
$$

In the profit function, we note that the only heterogeneity across firms is in the marginal cost of firm $i, c_{i}$, and in the firm's output choices (which are, of course, a function of $c_{i}$ in equilibrium). This marginal cost is inversely proportional to firmlevel productivity and, in extended models, can be a function of factor and input prices. ${ }^{15}$ In the literature, it is common to assume that transport costs and fixed costs are homogeneous across all firms, although in reality firms may face heterogeneous trade costs exogenously or endogenously (section four discusses ways in which costs may be endogenous through trade finance).

As mentioned above, firms maximize profits by choosing quantities. Suppressing $i$ 's for the remainder of the manuscript-understanding that $c$ defines a given firm producing a particular product-the maximization problem yields optimal pricing for the export market,

$$
p(q)=\frac{\varepsilon(q)}{\varepsilon(q)-1}(\tau c+s) t,
$$

where $\varepsilon(q)=-\frac{d p}{d q} \frac{q}{p}$ is the elasticity of demand in absolute terms. Depending on the assumption over the utility function, this elasticity may be constant (CES, as in Krugman 1980 and Melitz 2003), variable and falling in output (Melitz and Ottaviano 2008), or may have some other properties (see Mrázová and Neary 2015, for a general treatment of the convexity of demand and selection into exporting).

Of note, the price derived in (2) is the consumer price, and this price can be broken up into three terms: the mark-up $\left(\frac{\varepsilon(q)}{\varepsilon(q)-1}\right)$, marginal costs $(\tau c+s)$, and the tariff adjustment factor $(t)$. Note, however, that the tariff factor does not affect the price that the producer receives, $\frac{p(q)}{t}$, unless it affects the mark-up. This will have an

\footnotetext{
${ }^{15}$ For this manuscript, we abstract from wage and other input prices. However, all results in this manuscript follow when assuming that costs are in labor units and that the costs include a scalar for the wage.
} 
important effect on the response of firms to a given set of international shocks, since the effect of the shocks will depend on the pricing conduct and market power of each firm, as embodied in the mark-up.

Implicitly, using the particular functional form of $p(q)$, equation (2) pins down the value of $q$ as a function of marginal costs and tariffs. The firm then solves for the profits of serving the export market and decides whether or not to enter. We now move to this basic entry decision, focusing on the role of trade costs and trade policy in the decision to export.

\subsection{Selection into Exporting}

The first decision a firm must make is whether to enter an export market or remain domestic. As specified in (1), the firm balances variable profits against a fixed cost of exporting when making this decision. ${ }^{16}$ Below, we describe this selection process using a variety of assumptions over the revenue function, and, later, we refer to this margin as the "extensive margin of trade"

\section{CES Demand}

Like the Krugman framework derived in section 2.1, the canonical model of exporting with heterogeneous firms, as developed in Melitz (2003), uses a constantelasticity demand function to model consumers. In this framework, the elasticity of demand is constant and equal to $\sigma$, and, hence, using (2) consumer prices are:

$$
p(q)=\frac{\sigma}{\sigma-1}(\tau c+s) t .
$$

Plugging into the revenue function, we find that profits are:

$$
\Pi=A t^{-\sigma}(\tau c+s)^{1-\sigma}-F_{x},
$$

\footnotetext{
${ }^{16}$ A separate literature has developed that allows for variable profits in multiple markets to be linked through the cost function, thereby making the entry decision more complicated. See Ahn and McQuoid (2015); Spearot (2012); Blum, Claro, and Horstmann, (2013); McQuoid and Rubini (2014); Soderbery, (2014), and Spearot (2013b). Mora (2016) allows for markets to be linked through a financial constraint.
} 
where $A$ is function of aggregate variables and parameters, and, below, will represent a demand shifter in the export market. The firm chooses to enter the market in $d$ if the profits from doing so are greater than zero. In this case, variable profits are always positive due to the CES assumption (discussed below), so the question of selection boils down to whether these variable profits are greater than the fixed cost of exporting, $F_{x}$. Intuitively, this occurs if production costs are sufficiently low:

$$
c<\frac{1}{\tau}\left(\frac{A}{F_{x} t^{\sigma}}\right)^{\frac{1}{\sigma-1}}-\frac{s}{\tau} .
$$

Note that in (5), differently from Melitz (2003), we have included ad valorem tariffs as well as per-unit transport costs. Indeed, with the addition of per unit costs, it is clear that if per-unit costs are sufficiently high, there exists no positive range of production costs, $c$, such that trade occurs. That is, there are "trade zeros" through endogenous firm selection. Although different from the treatment of trade zeroes in Helpman, Melitz, and Rubinstein (2008), where trade zeros occur because of a bounded distribution of productivity (firms can only be so good), this result highlights how natural forces of geography and trade costs can limit trade, not only by firms, but also between countries.

For clarity, we now simplify the model to that in the original Melitz (2003) framework, where there are no tariffs, $t$, and no per-unit transport costs, $s$. In this case, exporting occurs if:

$$
c<\frac{1}{\tau}\left(\frac{A}{F_{x}}\right)^{\frac{1}{\sigma-1}} .
$$

In (6), we find a number of intuitive relationships between trade costs and selection into exporting. Both the fixed costs of exporting and the iceberg transport cost, when larger, reduce the range of marginal costs so that exporting occurs. That is, with higher trade costs, to successfully export a firm must be even more productive. Importantly, this equation also makes it clear that destination-market factors, such as the demand shifter $A$, affect the incentives to export and the role of trade costs. Indeed, a more distant market can support more exporting if the market size is large enough to compensate for the additional costs of trade. Empirically, this is an 
important issue to consider, since it suggests a necessary empirical strategy that requires destination-market effects, potentially by industry.

\section{Non-CES Demand}

CES demand holds special properties that, while making analysis tractable, are empirically implausible. In particular, under the assumption of monopolistic competition, demand is always positive, regardless of the price, and demand values are asymptotic to infinite values when prices are low enough. Ironically, baked into the CES framework-which usually requires that firms be small-is the possibility that a firm is extremely large as it gets very productive. To move away from the possibility of "super firms" within a model of monopolistic competition, researchers have explored the use of other utility functions that may be less tractable but match the data better in this and other dimensions. The two most commonly used non-CES preferences are Translog and Continuum Quadratic. ${ }^{17}$

For the following section, we focus on the continuum quadratic, and, in particular, an extended version of the Melitz and Ottaviano (2008) utility function. Precisely, continuum quadratic preferences yield a (linear) inverse demand function, represented by $p(q)=A(Q)-b q$, where $A(Q)$ is an aggregate term that is decreasing in quantity sold to consumers in that market by all firms. However, as motivated above, to keep firms small, we assume firms take $A$ as given. With this linear demand function and the assumption of small firms, the profit maximizing producer price from (2) is simplified as:

$$
\frac{p(q)}{t}=\frac{A+(\tau c+s) t}{2 b t} .
$$

Here, we find a number of interesting differences between linear and CES demand functions in terms of the effects of trade costs and trade policy. Most importantly, we find that producer prices are not proportional to marginal costs, either the costs

\footnotetext{
${ }^{17}$ Feenstra (2014) outlines a firm-heterogeneity model using a general form of homothetic preferences with variable elasticities. Bertoletti, Etro, and Simonovska (2016) discuss the gains from trade in a utility function with indirect additivity. Rodriguez-Lopez (2011) develops a firm-heterogeneity model using a translog expenditure function.
} 
related to firm-level production or those related to transportation. This results from the variable elasticity of demand under the assumption of linear demand, and, in particular, the assumption that absolute elasticities fall with lower costs (higher output).

Plugging (8) into the revenue function, profits under linear demand with fixed exporting costs are written as:

$$
\Pi=\frac{(A-(\tau c+s) t)^{2}}{4 b t}-F_{x}
$$

where it is clear why linear demand becomes less tractable with fixed exporting costs. While it is true that lower costs increase the probability of exporting, the functional form of this cutoff is far less tractable than that of CES. Precisely, firms export if costs meet the following condition:

$$
c<\frac{1}{\tau t}\left(A-2 \sqrt{b t F_{x}}\right)-\frac{s}{\tau} .
$$

As with CES, if the per-unit costs of transportation $s$ are too high, no firm will be of sufficient productivity to export. However, unlike with CES, even when per-unit costs of transportation are zero, it is still possible that no firm will export. Specifically, setting $s$ equal to zero in (9), we have:

$$
c<\frac{1}{\tau t}\left(A-2 \sqrt{b t F_{x}}\right) .
$$

Intuitively, since monopolists never produce beyond the point of unit elasticity, revenues are bounded under linear demand. Thus, if the fixed costs of export are too high, no firm with a positive marginal cost can enter the export market.

Given these properties, the literature rarely uses fixed exporting costs with linear demand. Instead, the literature focuses on selection through the iceberg cost (Melitz and Ottaviano 2008), or the tariff (Spearot, 2013a), where the selection condition is simply $c<\frac{A}{\tau t}$. Additionally, selection in the linear model is also proportional to demand levels and trade costs, as in CES. So, while the linear model is slightly more restrictive in terms of the types of transport costs that are used, the model is similar in the use of ad valorem trade costs, and it ultimately facilitates an elegant analysis of trade in which mark-ups may vary. 


\section{$2.4 \quad$ Firm-Level Trade}

The role of trade costs does not end with the decision to export or not. In particular, there are a variety of variable trade costs that can affect the intensity with which firms trade; we refer to increases in average exports by firms as the intensive margin of trade in section three. Next, we briefly examine these incentives within the CES and linear demand models.

\section{CES Demand}

Returning to the CES model, firm-level trade revenues, conditional on trading, are easily derived as:

$$
v=\sigma A t^{-\sigma}(\tau c+s)^{1-\sigma} .
$$

To evaluate the role of market and trade costs shocks on this value, we logdifferentiate (11) with respect to $A$, and all trade cost and trade policy parameters.

$$
\widehat{v}=\widehat{A}-\sigma \hat{\boldsymbol{t}}-(\sigma-1) \frac{\tau c}{(\tau c+s)} \hat{\boldsymbol{\tau}}-(\sigma-1) \frac{s}{(\tau c+s)} \hat{\boldsymbol{s}} .
$$

Here, "hats" refer to percentage changes in the variable. Equation (12) makes it clear that, under the assumption of CES demand, firm-level trade revenues change proportionally with demand shifters and tariffs, and proportionally with other changes in trade costs scaled by their cost share. Unfortunately, iceberg and per-unit trade costs are typically not measured separately (if at all), so determining the cost shares of different types of trade costs would prove a difficult endeavor. However, as described above, one could argue that the former are related to insurance and value and the latter to weight, which would give a sense of their cost shares.

Typically, the literature uses the iceberg cost interchangeably as both a "distance" and "trade policy" parameter. Equation (12) makes it clear that this interpretation is not correct for two reasons. First, even if there are no per-unit transport costs, the elasticity of firm-level trade with respect to tariffs is larger than the elasticity with respect to trade costs. This is because the tariff reduces revenues 
directly, and also through the optimal choice of quantity. ${ }^{18}$ For iceberg costs, the only effect on revenue is through the optimal choice of quantity. Second, with nonzero per-unit trade costs, it is clear that any elasticity with respect to distance is contaminated if the share of ad valorem costs is not measured appropriately.

\section{Non-CES Demand}

The analysis of demand and trade shocks under the assumption of linear demand is more complicated. First, note that firm-level trade revenues are derived as:

$$
v=\frac{A^{2}-t^{2}(\tau c+s)^{2}}{4 b t}
$$

Log differentiating (13) with respect to $A$ and all trade cost and trade policy parameters yields a reasonably complicated function related to parameters, trade cost shocks, and the latter's share of marginal costs. However, as shown in Spearot (2013a), this effect of trade shocks can be simplified as follows:

$$
\widehat{v}=\frac{A^{2}}{2 b t v}\left(\widehat{A}-\hat{\boldsymbol{t}}-\frac{\tau c}{(\tau c+s)} \hat{\boldsymbol{\tau}}-\frac{s}{(\tau c+s)} \hat{\boldsymbol{s}}\right)+\hat{\boldsymbol{t}} \text {. }
$$

Finally, noting that the highest value of revenues that a firm can earn with linear demands is $v_{\max }=\frac{A^{2}}{4 b t^{\prime}}, \mathbf{( 1 4 )}$ can be further simplified to:

$$
\widehat{v}=2 \frac{v_{\max }}{v}\left(\widehat{A}-\hat{t}-\frac{\tau c}{(\tau c+s)} \hat{\boldsymbol{\tau}}-\frac{s}{(\tau c+s)} \hat{s}\right)+\hat{t} .
$$

Equation (15) makes clear the effect of trade costs, trade policy, and demand shocks in an environment with demand that is more inelastic for higher quantities. Within the parentheses in equation (15), the effects of trade cost and policy shocks are similar to those with CES. However, all trade shocks must be weighted by firm-level export revenues, $v$, and it is predicted that a given set of shocks will be less pronounced in percentage terms on firm-level trade when the firm is larger (more productive).

\section{$2.5 \quad$ Aggregating Firm-level Trade}

\footnotetext{
${ }^{18}$ To see this in (11), note that the effect through the optimal choice of quantity is simply through the revenue function $-(\sigma-1)$. With the extra cost of tariffs for the firm, we reduce this exponent by one to $-\sigma$.
} 
A crucial component of firms in trade, and a major innovation in the analysis of world trade flows, is aggregating the decisions of firms into country-level trade flows. Starting with Helpman, Melitz, and Yeaple (2004) and Chaney (2008), the most common method of aggregating firms is to use the Pareto distribution to represent heterogeneity in the costs of production. The use of the Pareto distribution is empirically supported in a wide number of studies (Eaton, Kortum and Kramarz 2011, Di Giovanni, Levchenko, and Rancier 2011), although recent research has extended analysis to include a log-normal productivity distribution (Head, Mayer, and Thoenig 2014 and Fernandes et al. 2015).

For this paper, we move forward with the Pareto assumption due to its ease of use and reasonably strong support in the data. Precisely, we assume that in the exporting country, $N$ firms, some of which will fail immediately upon entry, have paid a fixed cost of entry and are potential exporters. After paying their entry costs, these $N$ firms draw a random value of marginal costs, $c$, from the following distribution:

$$
G(c)=\operatorname{Pr}(C<c)=\left(\frac{c}{c_{m}}\right)^{k},
$$

where, $c_{m}$ is the maximum value of costs in this distribution, and $k$ is the distribution's shape parameter. After firms draw their value of marginal costs, they make decisions regarding which markets to serve, and how much to sell to each market.

Assuming that $c_{m}$ is nonbinding (above the cutoff values for exporting), aggregate exports assuming CES preferences is derived using the following:

$$
V=N \int_{0}^{c^{*}} \sigma A t^{-\sigma}(\tau c)^{1-\sigma} g(c) d c,
$$

where $c^{*} \equiv \frac{1}{\tau}\left(\frac{A}{F_{x} t^{\sigma}}\right)^{\frac{1}{\sigma-1}}$ is the cost cutoff for exporting in CES. Imposing the Pareto distribution from (16) and integrating, we have:

$$
V=N \frac{k}{\sigma-1} t^{-k \frac{\sigma}{\sigma-1} \tau^{-k}} K_{c e s}
$$


where $K_{\text {ces }}$ is a constant of model parameters. In (18), we again see a distinct difference between the effects of tariffs and the effects of iceberg costs. First, the effects of tariffs are more pronounced and also a function of the shape parameter of exporters, and the destination-market demand elasticity. In contrast, the elasticity of trade with respect to iceberg costs is simply the shape parameter of the exporter.

For linear demand, the elasticity of demand is endogenous. However, using a similar procedure for linear demands, we can show that under the Pareto assumption the aggregate value of trade has a similar form:

$$
V=N A^{k+2} t^{-(k+1)} \tau^{-k} K_{l i n}
$$

where $K_{\text {lin }}$ is a function of model parameters related to the linear case. In (19), we see how firm-level trade aggregates to the observed bilateral trade value under two common modeling assumptions. On its face, the relationship between trade costs and tariffs and aggregate trade value are observationally equivalent between the two models. That is, in each model, trade costs are raised to the shape parameter and tariffs are raised to the power of a tariff elasticity. However, the interpretation of the tariff elasticity itself derives from different micro-foundations. ${ }^{19}$

As a final note on both the simplicity and the limitations of the canonical firm-heterogeneity models, we can solve for the average exporter trade flow, conditional on success to that market. This statistic is crucial since it represents the average firm size of the set of surviving firms, which is the set of firms that comprise reported trade data. Within the CES model of exporting, average export revenue, conditional on exporting, is written as:

$$
E[v \mid v>0]=\frac{\sigma k}{k-(\sigma-1)} F_{x} .
$$

In (20), we have a stark relationship between key parameters of the model and the average size of an exporter in the export market. Indeed, within the CES context, the only two places that could yield within-market variation in average export size are the elasticity of substitution and the fixed cost of exporting. Fernandes et al. (2015)

\footnotetext{
${ }^{19}$ Indeed, in terms of the direct effect of tariffs on the value of trade, the tariff elasticity under CES, $k \frac{\sigma}{\sigma-1}$, could be more responsive to firm heterogeneinty, $k$, in highly differentiated goods $(1<\sigma<2)$, when compared with the tariff elasticity under linear demand, $k+1$.
} 
use this stark result to motivate using a log-normal distribution of productivity to bring in endogenous effects of distance and market size to better match the model to data.

Within the linear model, average export revenue, conditional on exporting, is:

$$
E[v \mid v>0]=\frac{A^{2}}{2 b t(k+2)} .
$$

In contrast with the CES case in (20), we see in (21) a bit more destination-market influence in terms of the average size of the exporter. However, after controlling for tariffs and destination-market fixed effects, all remaining variation is captured by the exporter's shape parameter. Put differently, there is no bilateral variation in this statistic, as is possible in the CES case.

\subsection{Multi-Product Firms}

A key extension from the canonical firm-heterogeneity model is the ability of firms to export to more than one destination, and with more than one product. Indeed, as described in section one, the biggest exporters tend to be those that sell many products along with shipping to many destinations. Sending products to many destinations is a fairly straightforward extension of the Melitz-type models-from the same unit cost function, total production is split across multiple locations. There may be multiple locations to serve, and separate fixed costs per location, but profitability can be ranked and firms enter different markets accordingly.

In the case of multi-product firms, there are indeed some similarities, and, in a pinch, researchers could easily re-label destinations as products and gain some limited intuition about serving different products. However, this approach is undesirable for a few important reasons. First, firms often have a primary product, or a core competency, in which they specialize. In many cases, this product may have a higher revealed quality or a different cost structure than other products that they sell. An early paper to focus on these issues is Bernard, Redding, and Schott (2011), where firms receive a draw of product quality at the destination-product level and a firm-specific draw of productivity. From this point, the model proceeds in Melitz 
style, using a CES demand system with market-product-firm quality shifters. The authors show that firms exporting many products tend to serve more destinations, and have higher scale to each destination. Further, in response to declining trade costs globally, enhanced competition forces firms to drop their least-profitable products. ${ }^{20}$

On this last point, the second important extension related to multi-product firms is that the costs of producing one variety may be linked in either variable of fixed terms to other varieties, thereby creating a linkage between the decision to sell one product to the market and the decision to sell other products to the same or other markets. In these types of models, trade shocks can force different firms to rationalize the varieties they sell based on the efficiency of scope. Arkolakis, Ganapati, and Muendler (2015) propose a CES-based model, in which firms have a core-competency-the product that the firm produces most efficiently. Other products can be produced, but at a lower efficiency. Further, there are diseconomies of scope in producing many varieties, which depend on how far away from the core competency one produces. Using Brazilian data, their work estimates that products further from a firm's core competency incur higher unit costs, but face lower market access costs.

Third, different products sold to the same market raise the issue of withinfirm cannibalization of varieties. That is, when selling differentiated but similar varieties to the same market, each variety steals some demand from the other within-firm variety. Feenstra and Ma (2008) and Eckel and Neary (2010) provide examples of this effect in two-country models. Dhingra (2013) evaluates the effect of tariff reductions on the number of products offered within each firm and the overall process efficiency of the firm. In her model, there is a tradeoff between more brands cannibalizing one another and increases in the profitability of process innovation with more brands. Global tariff cuts increase market size, which expands both process and product innovation for exporting firms. In contrast, non-exporting firms

\footnotetext{
${ }^{20}$ Goldberg et al. (2010) discuss the non-reallocation of firms and products in response to regulatory reform in India.
} 
face intensified competition and cut back on the number of products. Cannibalization has also been viewed through the lens of lower mark-ups, due to within- and across-firm competition. Spearot (2013a) and Mayer, Melitz, and Ottaviano (2016) use the basic framework of Melitz and Ottaviano (2008) to allow for multi-product firms selling to export destinations. In Mayer, Melitz, and Ottaviano (2016), firms focus on their best-performing products in markets with the toughest competition. They find strong evidence for this prediction using firm-level trade data from France. ${ }^{21}$

Finally, the newest area of work evaluates the linkages between the biggest multinationals and the scope of the products they sell around the world. As described by Yeaple (2013), Dupont, a major U.S.-based multinational, operates in over 70 countries and sells products ranging from food to motor vehicle parts to industrial chemicals (among many others). At a more refined level, recent work in Tintelnot (2016) provides an analytical framework to estimate the effects of exportplatform foreign direct investment, where firms invest in a distant location and use that location as a production source to export to other markets.

\subsection{Exporting and Investment}

The canonical model of selection into exporting can also be extended to allow for firm-level investment in productivity and quality. As in Dhingra (2013) above, from a neoclassical perspective, the incentives to invest are larger when market size increases. In the traditional firm-heterogeneity context, this has been studied through two primary mechanisms: quality and productivity investment. In Verhoogen (2008), firms invest in higher levels of quality, where reaching a higher quality level requires a fixed cost of investment. Similarly, Bustos (2011) examines productivity investment, where a higher productivity requires a fixed cost of investment. Interestingly, these two problems in their most basic form are isomorphic when using a CES revenue function, where higher-productivity firms

\footnotetext{
${ }^{21}$ In Spearot (2013a), the multi-product dimension is used to justify the choice of fixed effects, with firms entering at the HS4 level but producing varieties across many HS10 products.
} 
invest, whether for productivity or quality. Further, when trade costs fall, investment increases by adding less-productive firms that previously did not find investment profitable. As derived generally in Mrázová and Neary (2015), this results from super-modularity between productivity (or quality) and the costs of reaching the foreign market.

Arkolakis (2010) presents another extension to the canonical firmheterogeneity framework, in this case through investment in marketing expenditure. In his model, firms invest in marketing subject to a convex marketing cost, where marketing is more costly as you reach more consumers. Similar to Verhoogen (2008) and Bustos (2011), reduced costs of trade increase investment in marketing, which increases trade through a "new consumers" margin of trade. However, different from the canonical model, the elasticity with respect to trade costs is higher for small firms, as on the margin it is less costly for these firms to reach new consumers in response to a trade shock. Interestingly, this response to trade costs is qualitatively similar to the non-CES model as described in 2.4.

Another form of investment and self-selection is investment in becoming an importer. Similar to investing in productivity, becoming an importer is optimal if it reduces costs or increases competition among suppliers. Thus, if firms can overcome the fixed cost of becoming an importer, firms make this investment. This process is modeled in Amiti, Itskhoki, and Konings (2014), who develop a model to study exchange rate pass-through in an environment where firms can select into exporting and importing. Interestingly, in their model, self-selection into importing and exporting can mute the effects of exchange rate shocks. For example, an exchange rate appreciation in the country in question will have counteracting effects on the import and export sides of the business.

Finally, non-CES models have been used to a lesser degree to study the impact of investment on exporting and firm performance. Again, as characterized generally in Mrázová and Neary (2015), the typical selection patterns found in the CES-based literature-that high-productivity firms engage in investment-do not necessarily follow in an environment with non-constant elasticities, since it becomes possible that the profit function is no longer supermodular in productivity 
and costs of trade. Two recent examples are Rodriguez-Lopez (2014) and Spearot (2013b). In the former, the investment is in offshoring, in a model based on a translog expenditure function. In the latter, firms invest in capital within a linear demand framework. In both cases, there is an inverse-U-shaped relationship between productivity and the probability of investment. The intuition is that under common, non-CES demand systems, revenues will be bounded or the absolute elasticity decreases in quantity will be such that, on the margin, investment will not be profitable for large firms.

The discussion of firm heterogeneity and investment naturally leads to issues of exporter growth and dynamics. As exporting is a particularly costly endeavor, it is not a stretch to suggest that the decision to export is only the beginning of a complex set of decisions that require excellent management to ensure success. To this end, we now discuss export dynamics, and, in particular, how exporters grow or fail after reaching beyond their domestic borders.

\section{$3 \quad$ Firms and Export Dynamics}

In section one, we identified some key empirical findings that are difficult to reconcile with the classic trade model. In section two we described how selection between exporters and non-exporters is at the heart of the literature on firms in trade. Here, we elaborate further on some of the new, policy-relevant, questions firm-level studies are able to answer, using theoretical models similar to those in section two to explain some of the empirical findings described in section one.

\subsection{Self-Selection vs. Learning-by-Exporting}

While the stylized facts from section one make it clear that exporters are different from non-exporters, many studies do not explain the mechanism behind this finding. For instance, did the difference in firm characteristics exist before exporting, perhaps due to intrinsic characteristics of the firms, or do they result from the exporting decision itself? In the first case, the difference in firm characteristics 
exists whether or not firms export and the difference shows up only because the more-productive firms find it profitable to select into exporting. This "self-selection" of exporters was central to the theoretical mechanisms presented in section two of this paper. In the second case, there are none or fewer differences between firms before exporting occurs, and the difference shows up because the act of exporting helps exporters learn new, more-efficient production techniques. Naturally, the literature refers to this explanation as "learning-by-exporting." The distinction between these two different mechanisms is important, as identifying any causal relationship will lead to very different policy recommendations. For a summary of the findings in the papers discussed here, see Table 3.1.

One of the first studies to test for evidence of learning-by-exporting is Bernard and Jensen (1999).22 Using U.S. data, the authors find that there are differences between exporters and non-exporters and that the differences precede the act of exporting: firms that will export, compared with those that will not, are already larger in terms of employment and shipments, pay higher wages, and have higher productivity. Additionally, the differences in productivity and wage growth remain unchanged after exporting. To measure productivity, the authors calculate total factor productivity (TFP) using the residual of an estimated Cobb-Douglas production function. They then regress various performance measures on changes in export status with some controls for initial-firm characteristics. While productivity does not grow, they do find evidence that firm survival increases with exporting.

Clerides, Lach, and Tybout (1998) find similar results using a very different empirical strategy, in which they evaluate whether productivity trajectories for firms in Colombia, Mexico, and Morocco improve after exporting. The authors develop a model with endogenous and exogenous explanations for exporting status and productivity; in their model, marginal cost is endogenous because the exporting decision may affect marginal cost, and demand shifters (foreign income, exchange rates, prices of other products) are exogenous to the firm. To test for evidence of

\footnotetext{
${ }^{22}$ For a thorough summary of the learning-by-exporting vs. self-selection empirical literature covering 33 countries, see Wagner (2007).
} 
learning-by-exporting the authors simultaneously estimate both an autoregressive cost function and the choice to participate in exporting. They find that cost and productivity trajectories do not change after firms enter foreign markets, and they conclude that the positive association between exporting and productivity is purely driven by self-selection of more productive firms into exporting. ${ }^{23}$

While most studies find no evidence of learning-by-exporting, some find mixed evidence and others find evidence in special cases. Aw, Chung, and Roberts (2000), using a methodology similar to that of Bernard and Jensen (1999), find mixed evidence of learning-by-exporting: In Korea, TFP does not increase when firms export, but it does in Taiwan. The authors restrict the data to five industries that have high export participation rates and compare the productivity of similar plants that differ in export status. They conclude that the evidence supports neither the learning-by-exporting hypothesis nor the self-selection hypothesis. Casas, Díez, and González (2015) find weak evidence of learning-by-exporting. Firms that become exporters ("Entrants") experience an increase in TFP; evidence of learning, however, disappears once the authors control for firm size. Other studies find stronger evidence of learning-by-exporting in transitional and in least-developed economies. De Loecker (2007), using data from Slovenia and matched sampling techniques, finds that exporters become more productive after exporting and that the effect is stronger for those firms exporting to high-income regions. He argues that firms in economies in transition, such as Slovenia, have the most to learn from exporting. Van Biesebroeck (2005), using data from several least-developed countries in Africa and three different econometric methodologies, finds that the productivity advantage increases for firms after exporting. Van Biesebroeck argues that learning-by-exporting exists because, unlike other studies, his sample includes small domestic economies with poorly functioning credit markets.

Finally, in recent work, Atkin, Khandelwal, and Osman (2016) provide experimental evidence on learning-by-exporting in a randomized control trial with Eygptian rug manufacturers. Specifically, after randomizing orders from an

\footnotetext{
${ }^{23}$ For other papers that test for and don't find evidence of learning-by-exporting, see Isgut (2001), using data from Colombia, and Bernard and Jensen (2004), using U.S. data.
} 
international rug intermediary across small rug makers, they evaluate in a laboratory setting whether those receiving export access became more skilled at making high-quality rugs. Employing external evaluators of rug quality, they find strong evidence in favor of learning-by-exporting.

Table 3.1: Summary of Learning-By-Exporting Literature

\begin{tabular}{|l|c|l|}
\hline \multicolumn{1}{|c|}{ Paper } & $\begin{array}{c}\text { Learning-By- } \\
\text { Exporting? }\end{array}$ & \multicolumn{1}{|c|}{ Data } \\
\hline Bernard and Jensen (1999) & No & United States \\
\hline $\begin{array}{l}\text { Clerides, Lach, and Tybout } \\
(1998)\end{array}$ & No & Colombia, Mexico, and Morocco \\
\hline Isgut (2001) & No & Colombia \\
\hline Bernard and Jensen (2004) & No & United States \\
\hline Aw, Chung, and Roberts (2000) & Yes & Korea \\
\hline Aw, Chung, and Roberts (2000) & Weak & Colombia \\
\hline Casas, Díez, and González (2015) & Yes & $\begin{array}{l}\text { Burundi, Cameroon, Cote d'Ivoire, } \\
\text { Ethiopia, Ghana, Kenya, Tanzania, } \\
\text { Zambia, and Zimbabwe }\end{array}$ \\
\hline Van Biesebroeck (2005) & Yes & Slovenia \\
\hline $\begin{array}{l}\text { De Loecker (2007) } \\
\text { Atkin, Khandelwal, and Osman } \\
\text { (2016) }\end{array}$ & Yes & Egyptian Rug Manufacturers \\
\hline
\end{tabular}

\subsection{Aggregate Productivity Improvements}

Even if exporting does not lead to improvements in productivity at the firm level, it is nevertheless possible that exporting leads to productivity improvements at the sector level. Here, it is important to note the role of import competition in driving self-selection. That is, in isolation, lower tariffs in an export market reduce the average productivity of firms that can reach the market (since it is now easier to sell 
profitably in that market). However, during liberalization episodes that involve cutting tariffs globally, the surge in imports with resulting higher wages due to increased export demand leads to a market with lower domestic margins and, consequently, drives out the least-productive firms. That is, trade liberalization increases average productivity through self-selection.

Aw, Chung, and Roberts (2000), Pavcnik (2002), and Bernard and Jensen (2004) all find evidence that productivity indeed rises at the industry level after trade liberalization, as the least-productive firms exit the market and resources are reallocated to more-productive firms. Clerides, Lach, and Tybout (1998) argue that firms may not benefit exclusively from exporting; that is, firms may learn from exporting, but domestic-only firms are not excluded from the cost reductions. Thus, they not only find, as mentioned above, no evidence of learning-by-exporting, but they also find that increases in export activity decrease average variable costs within a region.

\subsection{The Intensive Margin vs. the Extensive Margin of Trade}

While productivity differences may explain why few firms export and why few exporters dominate export value, it does not fully explain the export dynamics observed in the data. For example, is export growth led by the intensive margin, as exports per firm increase, or is export growth led by the extensive margin, as the number of firms exporting increases? As shown in section two of this paper, changes in trade costs most clearly impact the extensive margins of trade when using the Pareto distribution to represent firm heterogeneity. In the model, fixed export costs determine whether or not a firm exports, and variable trade costs (tariffs/transportation costs) affect prices and, thus, sales abroad. However, since lower variable trade costs and lower fixed export costs draw in firms on the margin to export, the impact of these changes on exports per firm at the country level is ambiguous, and export growth is driven exclusively by the new exporters. ${ }^{24}$ This

\footnotetext{
${ }^{24}$ See section two for a discussion of the determinants of average export flows.
} 
finding contrasts with those of previous models, where trade liberalization would affect only the intensive margin (that is, through the production choices of a fixed number of exporters).

Recent empirical work has identified several important facts about the intensive margin, in contrast with our theoretical model above. First, the alreadymentioned work by Fernandes et al. (2015) uses data from the World Bank covering 50 developing countries to evaluate trade growth on the intensive and extensive margin. They develop a Melitz-style model of exporting, but with a log-normal distribution of productivity. They estimate the model using maximum likelihood, and find that half of the variation in exports occurs along the intensive margin. Second, Lawless (2010) uses U.S. Census Bureau data and finds that distance-in contrast with other gravity variables such as language, internal geography, and import cost barriers-lowers the intensive margin. Finally, Das, Roberts, and Tybout (2007), using Colombian data, find that reductions in trade costs, enhanced export promotion, and moderate depreciation of the exporting country's exchange rate all result in increased trade on the intensive margin. ${ }^{25}$

While these empirical findings make the argument that the intensive margin should not be ignored, the evidence nonetheless implies that the extensive margin explains most of the export dynamics seen in the data. A key reason, as mentioned in section one, is the importance of new exporters on future export growth. Eaton et al. (2007), for example, find that new exporters contribute little to overall revenues when entering the export market, but will account for almost half of total export growth within a decade. In addition to Eaton et al. (2007), Mayer and Ottaviano (2008) and Bernard et al. (2007) also argue that the extensive margin is much more important. Mayer and Ottaviano (2008) find empirical evidence suggesting that distance and other trade barriers correlated with distance reduce the number of exporters, but not average exports per firm. Bernard et al. (2007) find evidence using U.S. data for the importance of the extensive margin; they argue that

\footnotetext{
25 This result is especially strong in sectors with firms that are clustered far from the export entry margin.
} 
economies of scale and sunk costs may lead firms to expand the number of products/destinations.

The relative importance of the extensive and intensive margins of trade is the focus of several models. Here, we focus on two: Helpman, Melitz, and Rubinstein (2008) and Das, Roberts, and Tybout (2007). Helpman, Melitz, and Rubinstein (2008) develop a model that decomposes trade flows into the intensive and extensive margins of trade, including the possibility of zero trade flows. They argue that standard gravity regressions capture only the intensive margin of trade and fail to take into account selection. To account for the extensive margin, they use a firststage probit to account for selection into trade, and then a second-stage gravity regression to estimate trade flows conditional on these flows being positive. They find that the probability of exporting behaves in a similar way to trade volume in response to gravity factors and that the extensive margin may explain higher trade volumes when barriers are lowered. In an alternative model for the margins of trade, Das, Roberts, and Tybout (2007) estimate their model using a Bayesian Monte Carlo Markov chain estimator and firm-level data on three Colombian manufacturing industries: basic chemicals, leather products, and knitted fabrics. In contrast with their findings for the intensive margin, the extensive margin is likely to increase when many firms are clustered near their export-entry thresholds and either expectations about future market conditions improve or firms experience favorable shifts in the exchange rate. The effect is muted, as mentioned above, if firms are far from the entry threshold and most of the adjustments will take place through the intensive margin. Finally, the authors find that export promotion policies that subsidize exporter variable costs will have a larger impact on export sales than policies subsidizing fixed exporter costs. The authors argue that the latter policy is likely to bring in firms on the export-entry margin that will likely have relatively low export sales.

One aspect absent from the above discussion is that of financing entry into export markets. We save that discussion until section four, where we discuss the important issues of trade finance. Instead, we now end the firms and export dynamics discussion by summarizing the literature that seeks to understand why 
firms start small when they first export (and then grow) and the literature focusing on firms that fail at exporting.

\subsection{Why Firms Start Small}

There is another strand of the literature that focuses on firm dynamics, but that does not draw a clear distinction between the number of exporters (the extensive margin) and export value per firm (the intensive margin). This literature focuses on the finding that exporters tend to start small, in terms of sales, when entering the export market and then, conditional on surviving, increase sales. These firms, as mentioned in section one, play an important role in export growth. Studies seeking to reconcile these facts incorporate elements of both the extensive and intensive margins of trade. In general, these papers argue that firms learn about the success of their product only after exporting a small amount and that those firms finding that they are not competitive abroad exit the export market very quickly (the extensive margin). In contrast, successful exporters subsequently increase export sales (the intensive margin) and may even increase the number of products or destinations (the extensive margin). Albornoz et al. (2012) refer to this as "sequential exporting." In their model, export profitability is uncertain, but correlated over time and across destinations. Their model may explain why some new exporters give up shortly after entry, despite having paid high fixed export costs, and others increase sales and expand to other destinations. Their model also rationalizes why firms may start in smaller markets first, only expanding to larger markets after realizing export quality. They find evidence to support their mechanisms using data from Argentina. Conditional on survival, export growth will be higher after the first year than in subsequent years (23 percentage points higher), new exporters are more likely to enter other markets than continuous exporters (4.8 percentage points), and new exporters are more likely to exit the export market than continuous exporters (29 percentage points).

There are several other models that explain some of these new-exporter facts. In recent work, Eaton et al. (2014) develop a search-and-learning model 
where success in exporting reveals information about demand for a product, and a successful exporter will subsequently search for more buyers. The study uses the method of simulated moments to replicate key patterns in Colombian customs data and calculate the effect of trade costs and learning effects on exporter behavior. The authors quantify the role of several frictions and find that for new exporters the cost for finding one client in the United States every two years is $\$ 1,405$, and rises to $\$ 51,471$ to find one in one year. Once a client is found, the cost of finding another one drops to $\$ 106$ and $\$ 3,898$, respectively. On average, only one out of five potential foreign clients a firm meets will result in a successful partnership. In another example, Rauch and Watson (2003) focus more on importers in developed countries trying to identify firms in developing countries able to supply large orders. In their purely theoretical paper, firms in developed countries start with small orders under uncertainty to learn information about the supplier's capabilities, and exports sales grow for successful partnerships.

Finally, Morales, Sheu, and Zahler (2014) use the idea of "extended gravity" to explain why firms often export to markets that are similar to markets already served. In this model, bilateral trade liberalization increases exports not only to the partner's market, but also to other, similar markets. The argument is that entry costs to other, similar markets are lower after entering one of the markets, so trade liberalization with one country can have an impact on other, similar markets (even without trade liberalization in those other markets) through "extended gravity." The authors use matched, firm-level data from Chile in the chemicals sector to measure the importance of gravity and extended gravity and find that firms are more likely to export to countries that border or are in the same continent as a previous trading partner. The authors estimate that for Chilean firms: (1) market entry costs are lowered by $\$ 22,930$ when new markets border existing markets, (2) market entry costs of entering a similar country in South America are between $\$ 16,350$ and $\$ 18,970$, and (3) market entry costs outside of South America are between $\$ 94,860$ and $\$ 101,990$.

\subsection{Export Survival}


While most of the learning literature focuses on the dynamics of successful, new exporters, a strand of the literature focuses on the fact that most new exporters do not export beyond one year. ${ }^{26}$ This "export survival" literature attempts to understand what makes an exporter successful and what happens to the firm when it is not. This question is important, since, as mentioned above, several papers find that the costs of entering export markets are quite high and that export growth is led by the extensive margin. Additionally, first-time exporters, which tend to export small amounts the first time they export, likely experience a negative profit because of market entry costs, and this loss in turn may affect domestic performance. Mora (2016), for example, finds that financially constrained unsuccessful exporters are more likely to go out of business and experience lower domestic revenue and revenue growth than similar successful exporters and firms that have never tried exporting. The firm-level literature finds that exporting to closer markets improves export survival (Esteve-Pérez et al. 2007) and export success increases with the number of exporters, suggesting within-sector externalities (Cadot et al. 2013 and Stirbat, Record, and Nghardsaysone 2013).

As mentioned, financial constraints are one of the determinants of an exporter's success and, therefore, play a significant role in shaping the overall international trade flows. In the next section, we look precisely at how financial factors affect the exporters' performance and how exporters manage to finance their operations.

\section{$4 \quad$ International Trade and Finance}

Traditionally, the international economics literature has focused on the role of physical capital in determining the patterns of trade. In contrast, the role of financial capital has been mostly overlooked. Still, the workhorse trade models, including those mentioned in section two (Melitz 2003, Bernard et al. 2003), focused on the

\footnotetext{
${ }^{26}$ Here, we focus on firm-level studies, but there are studies that look at the survival of country-level export product lines and destinations (for example, see Besedeš and Prusa 2006).
} 
decisions made by individual firms to participate in international markets and provided the setting to incorporate financial elements into the firm's decisionmaking analysis. Why is this analysis relevant? There are a number of reasons why firms engaged in international trade deserve to be analyzed through a different lens from the typical (domestic) corporate finance considerations. Firms in international trade face situations where the time between the shipment of the product and its payment is significantly longer than for firms operating in the domestic market, creating special working capital needs. ${ }^{27}$ Additionally, in the case of a contract breach-either the importing firm's not paying for the delivered goods or the exporter's not sending the goods according to the agreed-upon specificationsthere is an increase in risk due to potential litigation in a foreign jurisdiction.

The literature can be (broadly) broken into two parts. First, a branch of the literature studies how firms' exporting outcomes are affected by country-, sector-, and firm-level financial factors. Second, another branch of the literature focuses directly on the financing of specific trade flows, the so-called trade finance and trade credit. $^{28}$ This literature looks at the determinants of how a given trade flow is, in one way or another, financed. We describe these different analyses next. ${ }^{29}$

\footnotetext{
${ }^{27}$ Foley and Manova (2015) report that international shipping and delivery typically takes 60 days longer than domestic transactions. This paper also provides an excellent survey of the recent literature intersecting corporate finance and international trade and investment.

${ }^{28}$ Typically, the term "international trade finance" refers to the set of contracts by which exporter and importer agree on the specific terms and conditions regulating their transaction. Still, sometimes the term "trade finance" is reserved for the financing of a transaction via the intermediation of a bank, while trade credit refers to the financing of one firm by the other. While it lies beyond the scope of this article to provide a detailed description, there is an abundant literature on trade credit, including Petersen and Rajan (1997), Burkart and Ellingsen (2004), Love, Preve, and Sarria-Allende (2007), and Klapper, Laeven, and Rajan (2012), to mention just a few.

${ }^{29}$ The literature on trade finance has also focused on the dynamics of international trade during financial crises, especially during the Great Trade Collapse (GTC) that took place during the 2008-2009 global financial crisis, when the fall in international trade far exceeded that of economic output. Some papers explain the GTC essentially as the result of demand shocks and compositional effects-see Eaton et al. (2016), Bems, Johnson, and Yi (2010), Behrens et a.l (2013), Brincogne et al. (2012), and Levchencko, Lewis, and Tesar (2010). Another group of papers emphasizes instead the role of financial factors, such as reduced access to capital-see Amiti and Weinstein (2011), Paravisini et al. (2015), Chor and Manova (2012), Ahn, Amiti, and Weinstein (2011), and Berman, de Souza, and Mayer. (2013). The general consensus is that demand and compositional issues played a primary role, while the trade finance considerations had a secondary, but still sizeable, effect.
} 


\subsection{Financial Considerations that Shape International Trade}

There are several ways by which finance can affect the resulting patterns of trade. For instance, the overall development of the financial system, a source of financial capital, establishes cross-country differences that enable firms from certain countries to have an advantage. Similarly, since some sectors have stronger needs for external funding, countries with more-developed financial systems facilitate access to capital and thereby enhance the ability of firms in certain sectors to enter external markets. Further, a firm's financial health also affects access to both capital and international markets. The literature studies the interaction between finance and trade at all of these different levels. We describe the main findings below and summarize the main factors considered by the literature in Table 4.1.

\subsubsection{Aggregate Financial Factors}

One group of papers studies the link between the development level of a country's financial system, the different sectoral external financial needs, and the resulting firms that enter international markets. ${ }^{30}$ Beck (2002) considers a model with two sectors, a homogeneous good and a differentiated good (with economies of scale). The model also includes a loan market with both asymmetric information and search costs. Critically, firms located in a financially more-developed economy face lower search costs, implying greater capital access. The model predicts that these financially developed economies have a comparative advantage in the differentiated-goods industry. Beck (2003) uses data for 56 countries and 36 industries and finds evidence that financially more-developed countries export relatively more in financially dependent industries. Manova (2008) provides additional evidence, supporting these results. Using data for 91 countries and the

\footnotetext{
${ }^{30} \mathrm{~A}$ country's level of financial development is usually proxied by variables such as credit to the private sector as a share of GDP, the value of the capital (equity) markets as a share of GDP, or the ratio of the financial system liabilities to GDP. Further, a sector's financial vulnerability is usually measured by external funding needs and tangible assets, following Rajan and Zingales (1998) and Claessens and Laeven (2003), respectively.
} 
1980-1997 period, she finds that opening equity markets to foreign capital increases exports, especially in sectors with higher external financing needs.

Manova (2013) also studies how financial frictions affect aggregate trade flows, but she incorporates elements of the current workhorse firm-heterogeneity trade model (Melitz). The paper specifically presents a multi-country, multi-sector model, with heterogeneous firms in terms of productivity, heterogeneous sectors in terms of external financing needs and collateralizable assets, and heterogeneous countries in terms of the probability of contract enforcement. ${ }^{31}$ In this setup, depending on the firm's need for external funding, credit constraints can increase the exporter's productivity cutoff or even reduce exports below their first best level. She then applies the model to a large dataset of 107 countries and 27 sectors spanning 1985 to 1995, and finds that around 20-25 percent of the total effect of credit constraints on trade is due to decreased output, one-third of the remaining (pure trade) effect is due to decreased entry into the export market, and the remaining two-thirds are due to decreased export sales. Further, countries that are financially more developed have less-acute credit constraints-therefore, they export more in sectors with higher external financing needs, export to more countries, and export more products.

\subsubsection{Firm-Level Financial Factors}

Another group of papers focuses on how firm-level financial considerations affect a firm's involvement in the export market. Greenaway, Guariglia, and Knelier (2007) examine whether a firm's financial health affects its export-market participation, where financial health is measured as either a firm's liquidity (the ratio of current assets minus current liabilities over total assets) or leverage (the ratio of short-term debt to current assets). The paper uses data on U.K. manufacturing firms for 1992-

\footnotetext{
${ }^{31}$ In most models, there is a clear (often one-to-one) correspondence between a firm's productivity and export performance with its ability to obtain external capital. This link becomes imperfect in Chaney (2016), where firms draw productivity levels and liquidity levels. Since export costs are financed through domestic sales and the liquidity endowment, some productive firms may not export if they draw a low liquidity level, while some low-productivity firms may export if they receive a high liquidity draw.
} 
2003 and finds that exporters present better financial health than non-exporters. ${ }^{32}$ However, these differences are essentially driven by continuous exporters that, consistent with the stylized facts presented in section one, tend to be larger than entrant exporters. New exporters actually present poorer financial health, possibly due to the sunk costs incurred to start exporting. Further, in a similar fashion to the discussion on self-election vs. learning-by-doing of section three, the paper also finds no evidence that firms with better ex ante financial health are more likely to start exporting, and strong evidence that participation in export markets improves firms' ex post financial health. ${ }^{33}$ The authors therefore conclude that financial health can be seen as an outcome rather than a determinant of export entry.

Recent work by Manova and Yu (2016) shows how credit constraints affect not just a firm's choice to export, but its export mode. There are three types of export modes in China: ordinary trade, import-and-assembly processing trade (where the processing firm sources and pays for imported inputs), and pureassembly processing trade (where the processing firm receives foreign inputs for free). While profitability increases from pure assembly to processing with imports to ordinary trade, more-profitable trade regimes require more working capital. The paper finds that financially healthier firms conduct more ordinary trade than processing trade and more import-and-assembly than pure assembly, and that financial health improvements are followed by reallocations towards more profitable modes. The impact of firm and sector financial health and vulnerability is bigger in Chinese provinces with weaker financial systems. Further, the paper also finds that the role of firm financial health as a determinant of the export mode choice is independent of firm size, age, productivity, ownership structure,

\footnotetext{
32 Several other papers also find that exporters present better financial health than non-exporters. For example, Muûls (2015) finds that among Belgian firms, credit ratings are correlated with exporter (and importer) status and exported (and imported) values. Berman and Héricourt (2010) use firm-level data from nine emerging economies and also find that financial health correlates with export status, but it does not increase the probability of remaining an exporter nor the size of exports. Minetti and Zhu (2011) use data on Italian firms and find that credit rationing affects both the extensive and the intensive margins of exporting. ${ }^{33}$ This is in contrast to Bellone et al. (2010), who, using data on French firms, find that firms enjoying better financial health are more likely to become exporters.
} 
production technology, and tariffs on imported inputs; and that its effect is economically large relative to that of firm productivity.

\subsection{How Are Trade Flows Financed?}

Since shipping goods internationally takes significant time, exporters and importers must agree not only on the price and quantity of a transaction, but also on who will finance the lag between production and delivery. Indeed, the firm that finances the transaction will bear the risk. These considerations translate into essentially three alternative contractual setups: an open account system where the exporter provides the financing (and bears the risk) by shipping the goods and waiting for the importer to receive them and only then receives payment, a cash-in-advance system where the importer provides the financing (and bears the risk) by paying to the exporter upfront, and a letter-of-credit system where the parties are financed by their respective banks. ${ }^{34}$ According to a report by the IMF (2009), the open account system is the one most commonly used, and comprises 42 percent of transactions, while the bank financing and the cash in advance systems amount to 36 percent and 22 percent, respectively.

There are a handful of recent papers that study how exporters and importers choose a specific type of contract to execute their transaction. In general, the literature identifies the degree of contract enforceability and the financing costs in both countries as the key factors for the contractual choice. For instance, SchmidtEisenlohr (2013) presents a model where the party from the country with the lower financing costs and weaker contract enforcement finances the transaction. When both parties are located in countries with weak contractual enforcement, bank financing is optimal since it resolves the commitment issues on both sides. The model also implies that trade finance costs are proportional to the value of the

\footnotetext{
${ }^{34}$ Banking finance actually includes other products, such as documentary collections, pre-export finance, and supply chain finance. A report from the BIS (2014) describes these alternative methods. The same report estimates that trade finance directly supports about one-third of global trade, around 6.5-8 trillion dollars per year, with letters of credit covering about one-sixth of total trade. Figure 1 presents a schematic representation of the workings of a letter of credit system, taken from Ahn (2015).
} 
exported goods, similar to the iceberg cost mentioned in section one. Several of the model's predictions are validated using a dataset that covers 150 countries between 1980 and 2004. In particular, the paper finds that two countries trade less with each other if their financing costs are higher and that this effect is larger the greater the distance (proxy for time to ship) between the two countries.

Antràs and Foley (2015) present another model of trade finance where cross-country differences in contractual enforcement drive the contractual choices made by the parties. The static version of the model predicts that open accounts or cash-in-advance are used (over letters of credit) as long as the banks from the importer's country can pursue claims against importers more effectively than exporters can. Additionally, the theory also predicts that the effect of the contractual environment on the financing choice is stronger the farther away the importer is from the exporter. The dynamic version of the model considers that a fraction of importers are not trustworthy, but the exporter learns about the importer's type and, through repeated interactions, may offer post-shipment financing terms. When they take these predictions to the data (of a U.S.-based food exporter), they find that indeed cash-in-advance and letters of credit are used most frequently with customers located in countries with relatively weak contractual enforcement measures. Still, the effect of weak contractual enforcement is reduced for importers in close proximity to the exporter. Further, they also find that as a relationship with an importer develops, it becomes more likely the firms will move to open account terms. This last result has important implications for policy, since it implies that developing a trading relationship can become a source of capital for firms located in countries with weak contractual environments.

Other papers focus directly on trade finance provided by banks. For instance, on a theoretical level, Ahn (2011) models the use of letters of credit in a setup where firms need capital from banks, which, in turn, need to invest to obtain information about both the importer and the exporter. Since international trade flows are smaller than domestic flows, banks invest less in the former type of transactions, making international trade relatively riskier. On an empirical level, Niepmann and Schmidt-Eisenlohr (2016) provide evidence on the role of letters of credit for 
exporting, using data on U.S. banks' trade finance claims. The paper's baseline result is that a one-standard-deviation negative shock to the country-level supply of trade finance leads to an average 1.5 percentage point decrease in export growth. Moreover, given the high degree of concentration in the business, a shock to a single large bank can affect U.S. aggregate export growth, and, since banks specialize in certain markets, a shock to a given bank will have heterogeneous effects across destination countries.

\section{5 - Conclusion and Directions for Future Research}

Our understanding of firms in international trade has expanded greatly over the last 20 years. However, there is much to be done to further our understanding of how firms, and in particular big firms, operate in the global economy. Below, we address a few areas that could be the next frontier of research in this area.

Although many of our anecdotes and empirical analyses have clearly pointed to the critical role of big firms in international trade, the ability of the theory to capture the full extent observed in the data is still limited. For example, a large share of empirical models is motivated under the assumption of monopolistic competition, whereas, in reality, models of empirical industrial organization are likely more appropriate. Indeed, the entry of firms into new markets is not smooth-a small tariff change will likely not affect firm behavior much, although a large trade agreement or devaluation could have large effects on market entry. Atkeson and Burstein (2008), Eaton, Kortum, and Sotelo (2015), and Gaubert and Itskhoki (2015) pioneered early work studying the impact of shocks on discrete entry decisions, where potentially large firms enter based on an ordering of productivity. Continuing this line of research to study all aspects of firm decisions in response to international shocks will greatly enhance our understanding of firms in international commerce.

We also discussed various elements of firm dynamics, many of which have not been settled by empirical work, and future work would benefit from an 
introduction of elements recently identified in international trade. For example, the debate between learning-by-exporting and self-selection would benefit from studying the increasingly important role of intermediate goods in international trade. Vertical specialization may allow firms to produce items more efficiently and may allow firms to produce items that would not have been possible without an expansion of global supply chains. Likewise, since vertical specialization may increase the activity of firms in the global economy, it may affect the extensive margin as more firms export, and may affect the intensive margin as firms are able to export more. Thus, understanding the firm decision to import intermediate goods and to specialize in various parts of the global supply chain may provide insight in the discussion of learning-by-exporting versus self-selection and in the discussion of the extensive versus intensive margins of trade. Another potential direction of future research in understanding firm dynamics is the role of uncertainty in limiting exports. For example, Handley and Limao (2015) find that firm behavior changes significantly in the presence of policy uncertainty and firms may choose to delay entering a foreign market until conditions improve. Likewise, firms in developing countries that tend to have higher export failure rates may also delay entering markets. In fact, it may be that uncertainty limits the activity of firms abroad more than other trade costs and that policymakers should spend resources not only in order to increase market access but also to lower uncertainty (for example, helping potential exporters find partners abroad) or lowering fixed costs associated with exporting.

Finally, there are several directions in which the literature on trade and finance can move forward. First, trade finance theory could improve greatly by incorporating new layers of heterogeneity. Specifically, allowing for the optimal financing choice to depend on, for example, the product being traded, could shed new light into the analysis-as the characteristics of the goods affect the mode by which they are transported, it is reasonable to think that they also affect the payment choices, thus potentially creating a link between trade finance and the mode of transportation. Moreover, the literature could also incorporate elements usually considered in models of open economy macroeconomics-like exchange 
rate variation and expectations-as these surely play a significant role in determining whether a given transaction will be profitable. Further, the choice of the currency in which the transaction will take place also appears to be extremely relevant, yet very little is known about it. ${ }^{35}$ Last, but not least, probably the most important need of this literature is access to datasets on the different payment choices to enable identification of new stylized facts and to test future theories.

Table 4.1: Main Financial Variables Affecting Trade

\begin{tabular}{|c|c|}
\hline Country-level variables & $\begin{array}{ll}- & \text { Credit to the private sector to GDP ratio } \\
- & \text { Value of listed shares to GDP ratio } \\
- & \text { Financial sector liquid liabilities to GDP ratio } \\
- & \text { Indices of contract enforcement and expropriation } \\
& \text { risk }\end{array}$ \\
\hline Sector-level variables & $\begin{array}{l}\text { - External financing dependence } \\
\text { - } \text { Asset tangibility ratio } \\
\text { - } \text { Inventory to sales ratio } \\
\text { - }\end{array}$ \\
\hline Firm-level variables & $\begin{array}{ll}- & \text { Leverage ratio } \\
- & \text { Liquidity ratio } \\
- & \text { Credit rationing }\end{array}$ \\
\hline
\end{tabular}

\footnotetext{
${ }^{35}$ Casas et al. (2016) show the importance of currency invoicing in the reaction of trade flows to exchange
} rate variations. 


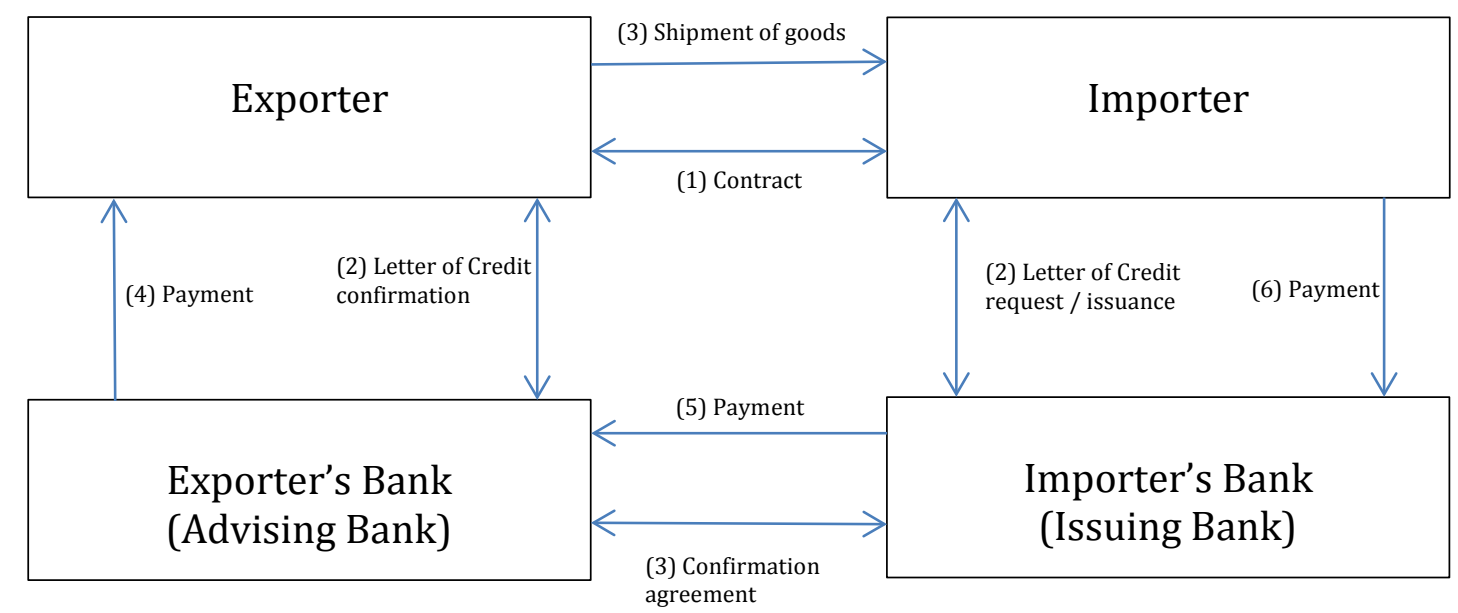

Figure 4.2: Letter of Credit System (Ahn 2015) 


\section{References:}

Ahn, J. 2011. A Theory of Domestic and International Trade Finance. IMF Working Papers, 11/262.

Ahn, J. 2015. Understanding Trade Finance: Theory and Evidence from TransactionLevel Data. International Monetary Fund, Washington, DC. manuscript.

Ahn, JaeBin, Mary Amiti, and David E. Weinstein. 2011. Trade Finance and the Great Trade Collapse. American Economic Review: Papers and Proceedings 101(3): 298302.

Ahn, J., \& McQuoid, A. F. (2015). Capacity constrained exporters: Identifying Increasing Marginal Cost. manuscript.

Albornoz, F., H. F. C. Pardo, G. Corcos, and E. Ornelas. 2012. Sequential Exporting. Journal of International Economics 88(1): 17-31.

Amiti, M., and D. E. Weinstein. 2011. Exports and Financial Shocks. Quarterly Journal of Economics 126(4): 1841-1877.

Amiti, Mary, Oleg Itskhoki, and Jozef Konings. 2014. Importers, Exporters, and Exchange Rate Disconnect. American Economic Review 104(7): 1942-1978.

Antràs, P., and F. C. Foley. 2015. Poultry in Motion: A Study of International Trade Finance Practices. Journal of Political Economy 123(4): 853-901.

Arkolakis, Costas. 2010. Market Penetration Costs and the New Consumers Margin in International Trade. Journal of Political Economy 118(6): 1151-1199.

Arkolakis, C., S. Ganapati, and M. A. Muendler. 2015. The Extensive Margin of Exporting Products: A Firm-Level Analysis. mimeo.

Atkeson, Andrew, and Ariel Burstein. 2008. Pricing-to-Market, Trade Costs, and International Relative Prices. American Economic Review 98(5): 1998-2031.

Atkin, D., A. K. Khandelwal, and A. Osman. 2016. Exporting and Firm Performance: Evidence from a Randomized Trial. National Bureau of Economic Research Working Paper No. 20690

Aw, B. Y., S. Chung, and M. J. Roberts. 2000. Productivity and Turnover in the Export Market: Micro-Level Evidence from the Republic of Korea and Taiwan (China). The World Bank Economic Review 14(1): 65-90. 
Beck, T. 2002. Financial Development and International Trade: Is There a Link? Journal of International Economics 57(1): 107-131.

Beck, T. 2003. Financial Dependence and International Trade. Review of International Economics 11(2): 296-316.

Behrens, K., G. Corcos, and G. Mion. 2013. Trade Crisis? What Trade Crisis? Review of Economics and Statistics 95(2): 702-709.

Bellone, F., P. Musso, L. Nesta, and S. Schiavo. 2010. Financial Constraints and Firm Export Behaviour. The World Economy 33(3): 347-373.

Bems, R., R. C. Johnson, and K. M. Yi. 2010. Demand Spillovers and the Collapse of Trade in the Global Recession. IMF Economic Review 58(2): 295-326.

Berman, N.,and J. Héricourt. 2010. Financial Factors and the Margins of Trade: Evidence from Cross-Country Firm-Level Data. Journal of Development Economics 93(2): 206-217.

Berman N, de Sousa J, Martin P, Mayer T. 2013. Time to Ship during Financial Crises. In NBER International Seminar on Macroeconomics 2012, 225-60. Chicago: Univ. Chicago Press.

Bernhofen, D. M., and Brown, J. C. 2004. A Direct Test of the Theory of Comparative Advantage: the Case of Japan. Journal of Political Economy, 112(1): 48-67.

Bernard, A. B.,and J. B. Jensen. 1999. Exceptional Exporter Performance: Cause, Effect, or Both? Journal of International Economics 47(1): 1-25.

Bernard, A. B., and J. B. Jensen, 2004. Exporting and Productivity in the USA. Oxford Review of Economic Policy 20(3): 343-357.

Bernard, A. B., Eaton, J., Jensen, J. B., and Kortum, S. 2003. Plants and Productivity in International Trade. American Economic Review, 93(4): 1268-1290.

Bernard, A. B., J. B. Jensen, S. J. Redding, and P. K. Schott. 2007. Firms in International Trade. Journal of Economic Perspectives 21(3): 105-130.

Bernard, A. B., S. J.Redding, and P. K. Schott. 2011. Multi-Product Firms and Trade Liberalization. Quarterly Journal of Economics, 126(3): 1271-1318.

Bernhofen, D. M., and Brown, J. C. 2004. A Direct Test of the Theory of Comparative Advantage: the Case of Japan. Journal of Political Economy, 112(1): 48-67. 
Bertoletti, Paolo, Etro Federico, and Ina Simonovska. 2016. International Trade with Indirect Additivity. National Bureau of Economic Research Working Paper No. 21984.

Besedeš, T., and T. J. Prusa. 2006. Product Differentiation and Duration of U.S. Import Trade. Journal of International Economics 70(2): 339-358.

BIS 2014. Trade Finance: Developments and Issues. CGFS Papers No. 50.

Blum, B. S., Claro, S., and Horstmann, I. J. 2013. Occasional and perennial exporters. Journal of International Economics, 90(1): 65-74.

Brander, James, and Paul Krugman 1983 A 'Reciprocal Dumping' Model of International Trade. Journal of International Economics 15(3): 313-321.

Brander, James A., and J. Spencer Barbara 1985. Export Subsidies and International Market Share Rivalry. Journal of International Economics 18(1): 83-100.

Bricongne, J. C., L. Fontagné, G. Gaulier, D. Taglioni, and V. Vicard. 2012. Firms and the Global Crisis: French Exports in the Turmoil. Journal of International Economics 87(1): 134-146.

Brooks, E. L. 2006. Why Don't Firms Export More? Product Quality and Colombian Plants. Journal of Development Economics 80(1): 160-178.

Burkart, M., and T. Ellingsen. 2004. In-Kind Finance: A Theory of Trade Credit. American Economic Review 94(3): 569-590.

Bustos, P. 2011. Trade Liberalization, Exports, and Technology Upgrading: Evidence on the Impact of MERCOSUR on Argentinian Firms. American Economic Review 101(1): 304-340.

Cadot, O., L. Iacovone, M. D. Pierola, and F. Rauch. 2013. Success and Failure of African Exporters. Journal of Development Economics 101: 284-296.

Casas, C., F. Díez, and A. González. 2015. Productivity and Export Market Participation: Evidence from Colombia. mimeo.

Casas, C., F. Díez, F., and A. González. 2016. Heterogeneous Exporters: Quantitative Differences and Qualitative Similarities. mimeo.

Casas, C., F. Díez, G. Gopinath, and P. Gourinchas. 2016. Dominant Currency Paradigm: A New Model for Small Open Economies. National Bureau of Economic Research Working Paper No. 22943. 
Chaney, Thomas. 2008. Distorted Gravity: The Intensive and Extensive Margins of International Trade. American Economic Review 98(4): 1707-1721.

Chaney, T. 2016. Liquidity Constrained Exporters. Journal of Economic Dynamics and Control 72: 141-154.

Chor, D., K. Manova. 2012. Off the Cliff and Back? Credit Conditions and International Trade during the Global Financial Crisis. Journal of International Economics 87(1): 117-133.

Claessens, S., and L. Laeven. 2003. Financial Development, Property Rights, and Growth. The Journal of Finance 58(6): 2401-2436.

Clerides, S. K., S. Lach, and J. R, Tybout. 1998. Is Learning by Exporting Important? Micro-Dynamic Evidence from Colombia, Mexico, and Morocco. Quarterly Journal of Economics 113(3): 903-947.

Das, S., Roberts, M. J., and J. R. Tybout. 2007. Market Entry Costs, Producer Heterogeneity, and Export Dynamics. Econometrica 75(3): 837-873.

Davis, D. R., and D. E. Weinstein. 2001. The Factor Content of Trade. National Bureau of Economic Research Working Paper No. 8637.

De Loecker, J. 2007. Do Exports Generate Higher Productivity? Evidence from Slovenia. Journal of International Economics 73(1): 69-98.

Deardorff, A. V. 1984. Testing Trade Theories and Predicting Trade Flows in R. W. Jones and P. B. Kenen (eds.) Handbook of International Economics, Volume 1: 467517.

Di Giovanni, J., A. Levchenko, and R. Ranciere. 2011. Power Laws in Firm Size and Openness to Trade: Measurement and Implications. Journal of International Economics 85(1): 42-52.

Dhingra, S. 2013. Trading Away Wide Brands for Cheap Brands. American Economic Review 103(6): 2554-2584.

Eaton, J., M. Eslava, C. J. Krizan, M. Kugler, and J. Tybout. 2014. A Search and Learning Model of Export Dynamics. mimeo.

Eaton, J., M. Eslava, M. Kugler, and J. Tybout. 2007. Export Dynamics in Colombia: Firm-Level Evidence. National Bureau of Economic Research Working Paper No. 13531.

Eaton, Jonathan, and Gene M. Grossman 1986. Optimal Trade and Industrial Policy under Oligopoly. Quarterly Journal of Economics 101(2): 383-406. 
Eaton, J., S. Kortum, and F. Kramarz. 2011. An Anatomy of International Trade: Evidence from French Firms. Econometrica 79(5): 1453-1498.

Eaton, J., S. Kortum, B. Neiman, and J. Romalis. 2016. Trade and the Global Recession American Economic Review 106(11):3401-3438.

Eaton, Jonathan, Samuel Kortum, and Sebastian Sotelo. 2015. International Trade: Linking Micro and Macro. Advances in Economics and Econometrics: Tenth World Congress, Volume II, Applied Economics.

Eckel, C., and J. P. Neary. 2010. Multi-Product Firms and Flexible Manufacturing in the Global Economy. Review of Economic Studies 77(1): 188-217.

Esteve-Pérez, S., J. A. Mánez-Castillejo, M. E. Rochina-Barrachina, and J. A. SanchisLlopis. 2007. A Survival Analysis of Manufacturing Firms in Export Markets in (eds.) J. M. Arauzo-Carod and M. C. Manjon-Antolin, Entrepreneurship, Industrial Location, and Economic Growth. Edward Elgar Publishing Limited.

Feenstra, Robert C. 2014. Restoring the Product Variety and Pro-Competitive Gains from Trade with Heterogeneous Firms and Bounded Productivity. National Bureau of Economic Research Working Paper No. 19833.

Feenstra, R., and H. Ma. 2008. Optimal Choice of Product Scope for Multiproduct Firms, in (eds) Elhanan Helpman, Dalia Marin, and Thierry Verdier, The Organization of Firms in a Global Economy. Harvard University Press.

Fernandes, A. M., P. J. Klenow, S. Meleshchuk, . D. Pierola, and A. Rodríguez-Clare. 2015. The Intensive Margin in Trade: Moving Beyond Pareto. mimeo.

Foley, C. F., and Manova, K. (2015). International Trade, Multinational Activity, and Corporate Finance. Annual Review of Economics 7(1): 119-146.

Freund, C., and M. D. Pierola. 2016. The Origins and Dynamics of Export Superstars. IDB Working Paper No. 741.

Gandhi, A., S. Navarro, and D. A. Rivers. 2016. On the Identification of Production Functions: How Heterogeneous Is Productivity? mimeo.

Gaubert, Cecile, and Oleg Itskhoki. 2015. Granular Comparative Advantage. UC Berkeley, working paper.

Greenaway, D., A. Guariglia, and R. Kneller. 2007. Financial Factors and Exporting Decisions. Journal of International Economics 73(2): 377 -395. 
Goldberg, P. K., A. K. Khandelwal, N. Pavcnik, and P. Topalova. 2010. Multiproduct Firms and Product Turnover in the Developing World: Evidence from India. The Review of Economics and Statistics 92(4): 1042-1049.

Handley, K., and N. Limao. 2015. Trade and Investment under Policy Uncertainty: Theory and Firm Evidence. American Economic Journal: Economic Policy 7(4): 189222.

Head, Keith, Thierry Mayer, and Mathias Thoenig. 2014. Welfare and Trade without Pareto. American Economic Review 104(5): 310-316.

Helpman, E., M. Melitz, and Y. Rubinstein. 2008. Estimating Trade Flows: Trading Partners and Trading Volumes. Quarterly Journal of Economics 123(2): 441-487.

Helpman, E., Melitz, M. J., and Yeaple, S. R. 2004. Export versus FDI with Heterogeneous Firms. American Economic Review, 94(1): 300-316.

IMF. 2009. Sustaining the Recovery. World Economic Outlook. International Monetary Fund (October).

Irarrazabal, A., A. Moxnes, and L. Opromolla. 2015. The Tip of the Iceberg: A Quantitative Framework for Estimating Trade Costs. Review of Economics and Statistics 97(4): 777-792.

Isgut, A. 2001. What's Different About Exporters? Evidence from Colombian Manufacturing. Journal of Development Studies 37(5): 57 -82.

Johnson, Harry G. 1966. A Note on Tariff Valuation Bases, Economic Efficiency, and the Effects of Preferences. Journal of Political Economy 74(4): 401-402.

Klapper, L., L. Laeven, and R. Rajan. 2012. Trade Credit Contracts. Review of Financial Studies 25(3): 838-867.

Krugman, P. 1979. Increasing Returns, Monopolistic Competition, and International Trade. Journal of International Economics 9(4): 469-479.

Krugman, P. 1980. Scale Economies, Product Differentiation, and the Pattern of Trade. American Economic Review 70(5): 950-959.

Lawless, M. 2010. Deconstructing Gravity: Trade Costs and Extensive and Intensive Margins. Canadian Journal of Economics/Revue canadienne d'économique 43(4): 1149-1172.

Leamer, E. E. 1980. The Leontief Paradox, Reconsidered. Journal of Political Economy 88(3): 495-503. 
Leontief, W. 1953. Domestic Production and Foreign Trade; the American Capital Position Re-Examined. Proceedings of the American philosophical Society 97(4): 332349.

Levchenko, A., L. Lewis, and L. Tesar. 2010. The Collapse of International Trade during the 2008-2009 Crisis: In Search of the Smoking Gun. IMF Economic Review, 58(2): 214-253.

Love, I., Preve, L. A., and Sarria-Allende, V. (2007). Trade Credit and Bank Credit: Evidence from Recent Financial Crises. Journal of Financial Economics 83(2): 453469.

Manova, K. 2008. Credit Constraints, Equity Market Liberalizations and International Trade. Journal of International Economics 76(1): 33-47.

Manova, K. 2013. Credit Constraints, Heterogeneous Firms, and International Trade. Review of Economic Studies 80(2): 711-744.

Manova, K., and Z. Yu. 2016. How Firms Export: Processing vs. Ordinary Trade with Financial Frictions. Journal of International Economics 100: 120-137.

Mayer, T., M. J. Melitz, and G. I. Ottaviano. 2016. Product Mix and Firm Productivity Responses to Trade Competition. National Bureau of Economic Research Working Paper No. 22433.

Mayer, T., and G. I. Ottaviano. 2008. The Happy Few: the Internationalisation of European Firms. Intereconomics 43(3): 135-148.

McQuoid, A., and Rubini, L. 2014. The Opportunity Cost of Exporting. Unpublished manuscript.

Melitz, Marc J. 2003. The Impact of Trade on Intra-Industry Reallocations and Aggregate Industry Productivity. Econometrica 71(6): 1695-1725.

Melitz, Marc J., and Gianmarco I.P. Ottaviano 2008. Market Size, Trade, and Productivity. Review of Economic Studies 75(1): 295-316.

Minetti, R., and S. C. Zhu, S. C. 2011. Credit Constraints and Firm Export: Microeconomic Evidence from Italy. Journal of International Economics 83(2): 109125.

Mora, J. 2016. Export Failure and Its Consequences: Evidence from Colombian Exporters. mimeo. 
Morales, E.,G. Sheu, and A. Zahler. 2014. Gravity and Extended Gravity: Using Moment Inequalities to Estimate a Model of Export Entry. National Bureau of Economic Research Working Paper No. 19916.

Morrow, P., and D. Trefler. 2016. Endowments, Factor Prices, and Skill-Biased Technology: Importing Development Accounting into HOV. mimeo.

Mrázová, Monika, and J. Peter Neary. 2015. Selection Effects with Heterogeneous Firms. working paper.

Muûls, M. 2015. Exporters, Importers and Credit Constraints. Journal of International Economics 95(2): 333-343.

Niepmann, F., and T. Schmidt-Eisenlohr. 2016. No Guarantees, No Trade: How Banks Affect Export Patterns. International Finance Discussion Papers No. 1158. Board of Governors of the Federal Reserve System.

OECD-WTO. 2015. Aid for Trade at a Glance 2015: Reducing Trade Costs for Inclusive, Sustainable Growth.

Paravisini, D., V. Rappoport, P. Schnabl, and D. Wolfenzon. 2015. Dissecting the Effect of Credit Supply on Trade: Evidence from Matched Credit-Export Data. Review of Economic Studies 82(1): 333-359.

Pavcnik, N. 2002. Trade Liberalization, Exit, and Productivity Improvements: Evidence from Chilean Plants. Review of Economic Studies 69(1): 245-276.

Petersen, M. A., and R. G. Rajan, 1997. Trade Credit: Theories and Evidence. Review of Financial Studies 10(3): 661-691.

Rajan, R. G., and L. Zingales. 1998. Financial Dependence and Growth. American Economic Review 88(3): 559-586.

Rauch, J. E., and J. Watson. 2003. Starting Small in an Unfamiliar Environment. International Journal of Industrial Organization 21(7): 1021-1042.

Rodriguez-Lopez, J. A. 2011. Prices and Exchange Rates: A Theory of Disconnect. The Review of Economic Studies, 78: 1135-1177.

Schmidt-Eisenlohr, T. 2013. Towards a Theory of Trade Finance. Journal of International Economics 91(1): 96-112.

Soderbery, A. 2014. Market Size, Structure, and Access: Trade with Capacity Constraints. European Economic Review, 70: 276-298. 
Spearot, A. C. 2012. Firm Heterogeneity, New Investment and Acquisitions. The Journal of Industrial Economics, 60(1): 1-45.

Spearot, Alan C. 2013a. Variable Demand Elasticities and Tariff Liberalization. Journal of International Economics 89(1): 26-41.

Spearot, Alan C. 2013b. Market Access, Investment, and Heterogeneous Firms. International Economic Review 54(2): 601-627.

Stirbat, L., R. Record, and K. Nghardsaysone. 2013. Determinants of Export Survival in the Lao PDR. World Bank Policy Research Working Paper No. 6301.

Tintelnot, F. 2016. Global Production with Export Platforms. National Bureau of Economic Research Working Paper No. 22236.

Trefler, D. 1993. International Factor Price Differences: Leontief Was Right! Journal of Political Economy 101(6): 961-987.

Trefler, D. 1995. The Case of the Missing Trade and Other Mysteries. American Economic Review 85(5): 1029-1046.

U.S. Census Bureau. 2013. A Profile of U.S. Importing and Exporting Companies, 2010-2011. US Census Bureau News.

Van Biesebroeck, J. 2005. Exporting Raises Productivity in Sub-Saharan African Manufacturing Firms. Journal of International Economics 67(2): 373-391.

Vanek, J. 1968. The Factor Proportions Theory: The $\mathrm{n}$-factor Case. Kyklos, 21(4): 749-756.

Verhoogen, E.A. 2008. Trade, Quality Upgrading and Wage Inequality in the Mexican Manufacturing Sector. Quarterly Journal of Economics 123(2): 489-530.

Wagner, J. 2007. Exports and Productivity: A Survey of the Evidence from FirmLevel Data. The World Economy 30(1): 60-82.

Yeaple, S. R. 2013. Scale, Scope, and the International Expansion Strategies of Multiproduct Firms. National Bureau of Economic Research Working Paper No. 19166. 